\title{
Single amino acid changes in the predicted RNase H domain of Escherichia coli RNase G lead to complementation of RNase E deletion mutants
}

\author{
DAE-HWAN CHUNG, ${ }^{1}$ ZHAO MIN, ${ }^{2,3}$ BI-CHENG WANG, ${ }^{2}$ and SIDNEY R. KUSHNER ${ }^{1}$ \\ ${ }^{1}$ Department of Genetics, University of Georgia, Athens, Georgia 30602, USA \\ ${ }^{2}$ Department of Biochemistry and Molecular Biology, University of Georgia, Athens, Georgia 30602, USA
}

\begin{abstract}
The endoribonuclease RNase E of Escherichia coli is an essential enzyme that plays a major role in all aspects of RNA metabolism. In contrast, its paralog, RNase G, seems to have more limited functions. It is involved in the maturation of the 5 ' terminus of $16 S$ rRNA, the processing of a few tRNAs, and the initiation of decay of a limited number of mRNAs but is not required for cell viability and cannot substitute for RNase E under normal physiological conditions. Here we show that neither the native nor $\mathrm{N}$-terminal extended form of RNase $\mathrm{G}$ can restore the growth defect associated with either the rne-1 or $r n e \Delta 1018$ alleles even when expressed at very high protein levels. In contrast, two distinct spontaneously derived single amino acid substitutions within the predicted RNase $H$ domain of RNase $G$, generating the $r n g-219$ and $r n g-248$ alleles, result in complementation of the growth defect associated with various RNase $E$ mutants, suggesting that this region of the two proteins may help distinguish their in vivo biological activities. Analysis of rne $\Delta 1018 / \mathrm{rng}-219$ and $r$ re $\Delta 1018 / \mathrm{rng}-248$ double mutants has provided interesting insights into the distinct roles of RNase $E$ and RNase $G$ in mRNA decay and tRNA processing.
\end{abstract}

Keywords: mRNA decay; tRNA processing; rRNA maturation; chimeric proteins; cell viability

\section{INTRODUCTION}

Endoribonuclease E (RNase E) of Escherichia coli, encoded by the rne gene, is essential for cell viability and plays a major role in mRNA decay (Kuwano et al. 1977; Arraiano et al. 1988), rRNA maturation (Apirion and Lasser 1978; Li et al. 1999; Wachi et al. 1999), tRNA processing (Ray and Apirion 1981; Li and Deutscher 2002; Ow and Kushner 2002), and a variety of other aspects of RNA metabolism (Lundberg and Altman 1995; Lin-Chao et al. 1999; Masse et al. 2003). In contrast, RNase G, a protein that is $34 \%$ identical to the amino-terminal catalytic region of RNase $\mathrm{E}$ (amino acids 1-489) (Okada et al. 1994; Wachi et al. 1997), is not required for cell viability, is present in low abundance, and under normal physiological conditions cannot complement RNase E mutations (Wachi et al. 1997; Lee et al. 2002; Ow et al. 2003).

\footnotetext{
${ }^{3}$ Present address: Department of Cancer Biology, Scripps Florida, Jupiter, FL 33458, USA.

Reprint requests to: Sidney R. Kushner, Department of Genetics, University of Georgia, Athens, GA 30602, USA; e-mail: skushner@uga.edu; fax: (706) 542-3910.

Article published online ahead of print. Article and publication date are at http://www.rnajournal.org/cgi/doi/10.1261/rna.2104810.
}

While both enzymes employ a $5^{\prime}$-end-dependent mechanism for degrading RNA molecules (Mackie 1998; Tock et al. 2000), in vivo they appear to have significantly different substrate specificities. For example, RNase E is required for the processing of many tRNA precursors ( $\mathrm{Li}$ and Deutscher 2002; Ow and Kushner 2002), but in vivo most of these molecules are not effective substrates for RNase G (Ow et al. 2003; Deana and Belasco 2004). Furthermore, although both proteins are involved in generating the mature $5^{\prime}$ terminus of the 16S rRNA, they cleave the precursor at distinct sites (Li et al. 1999; Wachi et al. 1999).

One of the important distinctions between the two ribonucleases is that there is $\sim 25$-fold more RNase $\mathrm{E}$ than RNase G in E. coli on a molecule/molecule basis (Lee et al. 2002). Thus, it may not be surprising that increased expression (4.5-fold) (see Table 1) of the native RNase G protein, achieved by changing the copy number of the rng locus, did not lead to complementation of RNase E mutants (Wachi et al. 1997; Ow et al. 2003; Deana and Belasco 2004). However, much higher level expression (174-1440fold) (see Table 1) of two different extended forms of RNase $\mathrm{G}$ did result in weak growth in various rne mutants (Lee et al. 2002; Deana and Belasco 2004; Tamura et al. 2006). 
TABLE 1. Relative intracellular levels of RNase G

\begin{tabular}{|c|c|c|c|c|c|}
\hline Genotype & $\begin{array}{l}\text { Nature } \\
\text { of RNase G }\end{array}$ & $\begin{array}{l}\text { Copies } \\
\text { of } \\
\text { rng/cell }\end{array}$ & $\begin{array}{l}\text { Relative } \\
\text { amount }^{\text {a }}\end{array}$ & $\begin{array}{l}\text { RNase } \\
\text { G/RNase } E^{b}\end{array}$ & $\begin{array}{c}\text { Complementation } \\
\text { of } r n e \Delta 1018 \text { allele } \\
\text { by } r n g \text { plasmid at } \\
37^{\circ} \mathrm{C}^{\mathrm{C}}\end{array}$ \\
\hline$r n g^{+}$ & Wild type & 1 & 1 & $0.03^{b}$ & - \\
\hline$r n e^{+} / p U G K 24\left(r n g^{+}\right)^{d}$ & Wild type & $6-8$ & 1.6 & 0.05 & No \\
\hline$r n e^{+} / p \cup G K 31\left(r n g^{+}\right)^{d}$ & Wild type & $30-50$ & 4.5 & 0.13 & No \\
\hline$r n e^{+} / \mathrm{pDHK} 11\left({ }^{*} r n g^{+}\right)^{\mathrm{e}}$ & $\mathrm{N}$-terminal extended form & $6-8$ & 31.8 & 0.95 & No \\
\hline$r n e^{+} / \mathrm{pDHK} 3\left(\mathrm{rng}^{+}\right)^{\mathrm{f}}$ & Wild type & $6-8$ & 33.5 & 1.0 & No \\
\hline rne-1/pRNG3 $\left({ }^{*} \text { rng-his }{ }_{6}\right)^{g}$ & $\begin{array}{l}\text { N-terminal extended form with } \\
\text { six histidines at carboxy terminus }\end{array}$ & $6-8$ & 174 & 5.2 & Poor \\
\hline$r n e-1 /$ pRNG1200 $\left({ }^{*} r n g^{+}\right)^{\mathrm{h}}$ & $\mathrm{N}$-terminal extended form & $>100$ & 1440 & 43 & Poor \\
\hline$r n e^{+} / \mathrm{pDHK} 26(r n g-248)^{f}$ & Rng-248 & $6-8$ & 36.9 & 1.1 & Yes \\
\hline$r n e^{+} / \mathrm{pDHK} 28(r n g-219)^{\mathrm{f}}$ & Rng-219 & $6-8$ & 36.5 & 1.1 & Yes \\
\hline$r n e^{+} /$pDHK29 $(r n g-248)^{i}$ & Rng-248 & $1-2$ & 12 & 0.36 & Yes \\
\hline$r n e^{+} / \mathrm{pDHK} 30(r n g-219)^{\mathrm{i}}$ & Rng-219 & $1-2$ & 11.9 & 0.36 & Yes \\
\hline rne-1/pDHK34 (rng-219) & Rng-219 & $6-8$ & 1.4 & 0.05 & No \\
\hline \multicolumn{6}{|c|}{ 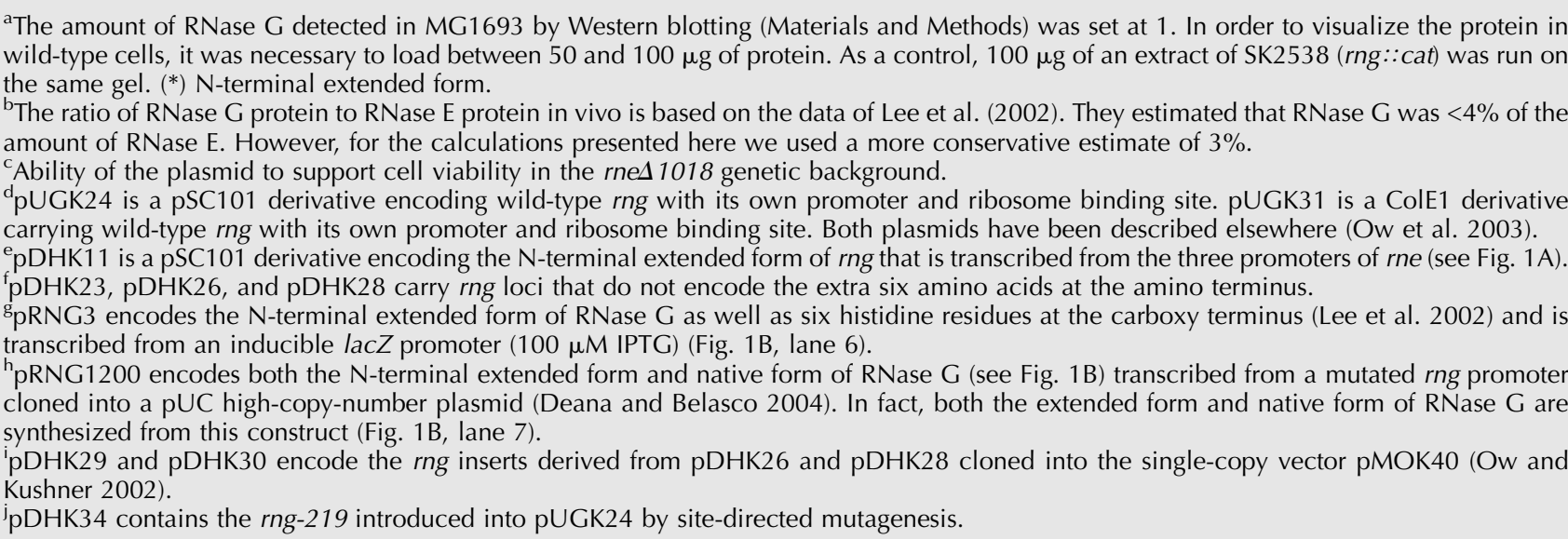 } \\
\hline
\end{tabular}

Although this approach represented a way to obtain limited complementation of the growth deficiency associated with the loss of RNase E activity, we wanted to investigate if RNase G could stably complement the absence of RNase E if it were expressed at intracellular levels that were comparable to how much RNase E was present (on a molecule/molecule basis) in wild-type cells. This experiment was of particular interest, since the computer-generated model for RNase $G$ presented here predicts that the protein has a threedimensional (3D) structure that is remarkably similar to that of RNase E (Fig. 4, see below). However, as described below a $>30$-fold increase in the intracellular level of either the native or the N-terminal extended form of RNase $G$, which led to protein levels comparable to those of RNase $\mathrm{E}$ in wildtype cells, did not complement either the rne-1 or rne $\Delta 1018$ allele. In contrast, spontaneously arising single amino acid substitutions within the predicted RNase $\mathrm{H}$ domain of RNase G (rng-219 and rng-248) led to proteins that complemented the growth defect associated with rne mutations when expressed at levels that were less than or equal to how much RNase E is present in wild-type E. coli. However, rne deletion mutants growing in the presence of either altered
RNase $G$ protein still exhibited significant defects in the decay of some mRNAs and the processing of tRNA precursors, while 9S rRNA maturation took place at almost wild-type levels.

\section{RESULTS}

\section{Overexpression of either the wild-type (489 amino acids) or the extended form (495 amino acids) of RNase $G$ does not complement rne mutants}

In order to obtain levels of RNase $G$ that were comparable to RNase E without using an inducible promoter, we replaced the $r n g$ regulatory region with the three promoters and ribosome binding site derived from RNase $\mathrm{E}$ (Ow et al. 2002). To ensure that only the native form of RNase G (489 amino acids) was synthesized, we changed the potential upstream translation start codon (GUG) to CUG, and a canonical ribosome binding site was inserted 7 nucleotides (nt) upstream of the AUG start codon (Fig. 1A, pDHK23). In addition, in order to try and reproduce the results of Lee et al. (2002) and Deana and Belasco (2004), we changed the upstream GUG codon to AUG to promote translation of 
(A)

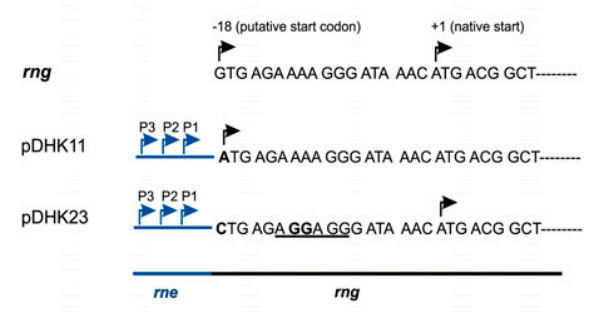

(B)

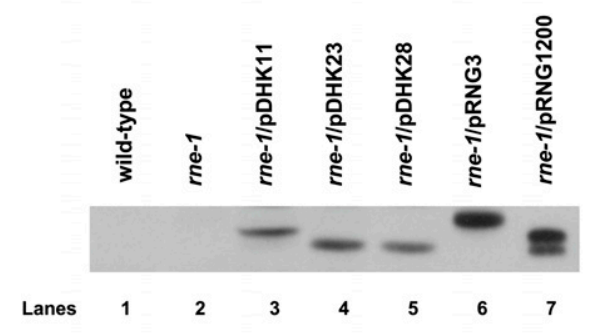

(C)

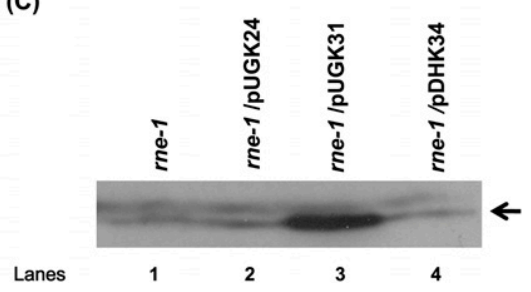

FIGURE 1. (A) Diagrammatic representation of the rng constructs in pDHK11 and pDHK23. The chromosomal rng sequence is shown at the top. The native translation start, identified by sequencing of the protein purified from E. coli (Briant et al. 2003) is shown as +1 . The translation start site employed by Lee et al. (2002) and Deana and Belasco (2004) is indicated as -18 . The upstream regulatory region of RNase $\mathrm{E}$ (shown to the left in blue), including its three promoters, as identified by $\mathrm{Ow}$ et al. (2002), was used to express $r n g$ in both pDHK11 and pDHK23. In pDHK11, the GTG translation start codon was changed to ATG and the RNase E ribosome binding site was inserted to increase translation efficiency. In pDHK23, the upstream GTG codon was changed to CTG to block potential translation initiation and a canonical ribosome binding site (underlined) was inserted 7 nt upstream of the RNase G native translation start codon (ATG). Altered nucleotides are shown in boldface. Rightward black arrows indicate translation start codons for the two constructs. Rightward blue arrows indicate the transcription start sites associated with the three RNase E promoters. (B) Western blot analysis of RNase $\mathrm{G}$ in various strains using $40 \mu \mathrm{g}$ (lanes 1-5), 20 $\mu \mathrm{g}$ (lane 6), or $2 \mu \mathrm{g}$ (lane 7) of total cell protein. Lane 1, MG1693; lane 2, SK6610; lane 3, SK3475; lane 4, SK3500; lane 5, SK3540; lane 6, SK5065; and lane 7, SK5067. pDHK11, pRNG3, and pRNG1200 encode an RNase $G$ protein that contains an extra six amino acids at the amino terminus (Fig. 1A). Based on the construction of pRNG1200 (Deana and Belasco 2004), both the native and extended form of the protein will be synthesized (lane 7). pRNG3 (Lee et al. 2002) encodes the extended form of RNase $\mathrm{G}$ along with six histidine residues at the carboxy terminus (lane 6). (C) Western blot analysis of RNase $\mathrm{G}$ in various strains using $100 \mu \mathrm{g}$ of total cell protein. Lane 1, SK6610; lane 2, SK2585; lane 3, SK2594; and lane 4, SK3559. The leftward arrow indicates RNase G. The relative quantities (RQ) of RNase G shown in Figure $1 \mathrm{~B}, \mathrm{C}$ are reported in Table 1. the extended form of RNase G (495 amino acids) (Fig. 1A, pDHK11). Both plasmids led to at least a $\sim 30$-fold increase in the level of the RNase G protein (Fig. 1B, lanes 3,4; Table 1). The protein produced by pDHK11 had a higher molecular weight, as expected (Fig. 1B, lane 3).

It has previously been shown that approximately one temperature-resistant revertant of SK6610 (rne-1 recA56) was obtained for every $10^{8}$ cells plated (Perwez et al. 2008). These colonies grew when restreaked at $44^{\circ} \mathrm{C}$ and were shown to contain intragenic second-site suppressor mutations (Perwez et al. 2008). In contrast, the presence of either pDHK11 or pDHK23 in SK6610 led to a $>200$-fold increase in the frequency of temperature-resistant survivors in a similar experiment. However, these isolates did not grow when restreaked directly at $44^{\circ} \mathrm{C}$, showing that there was not stable complementation of the growth defect.

To further confirm that neither pDHK11 $\left(\mathrm{Km}^{\mathrm{r}}\right)$ nor pDHK23 $\left(\mathrm{Km}^{\mathrm{r}}\right)$ could stably complement the loss of RNase $\mathrm{E}$ activity, we attempted to use these plasmids to displace a plasmid carrying the wild-type $r n e$ gene [pSBK1 $\left(r n e^{+} \mathrm{Cm}^{\mathrm{r}}\right)$ ] from an rne 1018 deletion strain (SK9714) (Ow et al. 2000), since all three plasmids carried the same origin of DNA replication (pSC101). However, after growing $\mathrm{Km}^{\mathrm{r}}$ transformants obtained with either pDHK11 or pDHK23 for more than 200 generations in the absence of $\mathrm{Cm}$ selection, no $\mathrm{Km}^{\mathrm{r}} \mathrm{Cm}^{\mathrm{s}}$ transformants were detected among the many thousands of colonies tested (data not shown).

\section{Two independent single amino acid changes in RNase $G$ lead to stable complementation of RNase $E$ mutants}

In order to isolate spontaneously arising RNase G mutants that could complement a complete rne deletion (rnes 1018) (Ow et al. 2000), we took advantage of the fact that a rne $\Delta 610$ truncation allele supports cell viability in the rne $\Delta 1018$ genetic background at $37^{\circ} \mathrm{C}$ but not at $44^{\circ} \mathrm{C}$ (Ow et al. 2000). Thus, in an rne $\Delta 1018$ strain carrying both the rne $\Delta 610\left(\mathrm{Cm}^{\mathrm{r}}\right)$ and mutant $r n g^{+}\left(\mathrm{Km}^{\mathrm{r}}\right)$ alleles on separate plasmids with identical origins of DNA replication, plasmid incompatibility should lead to $\mathrm{Km}^{\mathrm{r}} \mathrm{Cm}^{\mathrm{s}}$ survivors at $44^{\circ} \mathrm{C}$ that contained only mutated $r n g$ genes that could support cell viability.

Accordingly, we transformed a rne $\Delta 1018::$ bla/pMOK15 $(r n e \Delta 610) \mathrm{Cm}^{\mathrm{r}}$ strain (SK9957) with pDHK23 $\left(r n g^{+} \mathrm{Km}^{\mathrm{r}}\right)$ (Fig. 1A) (both pMOK15 and pDHK23 contain the same pSC101 origin of DNA replication) and selected for $\mathrm{Km}^{\mathrm{r}}$ $\mathrm{Cm}^{\mathrm{r}}$ transformants at $37^{\circ} \mathrm{C}$. These transformants were then grown for several hundred generations at $44^{\circ} \mathrm{C}$ in the presence of only $\mathrm{Km}$. Subsequently, when 1000 individual colonies were tested, $\sim 150$ were $\mathrm{Km}^{\mathrm{r}}$ and $\mathrm{Cm}^{\mathrm{s}}$. Significantly, these temperature-resistant survivors grew when restreaked at $44^{\circ} \mathrm{C}$. In addition, plasmid DNA isolated from six independent isolates displaced pSBK1 $\left(r n e^{+}\right)$from an rne $\Delta 1018$ deletion strain (SK9714) at either $30^{\circ} \mathrm{C}$ or $37^{\circ} \mathrm{C}$ and complemented the temperature-sensitive growth associated with the rne-1 allele in SK6610 (rne-1 recA56) at $44^{\circ} \mathrm{C}$. 
Sequencing of the rng insert, including the rne promoter region, from six independent plasmid isolates identified two distinct mutations in pDHK23. Two of the plasmids (one of which was named pDHK28) had a $\mathrm{G} \rightarrow \mathrm{T}$ transversion mutation in the rng coding sequence at the first base pair of the codon for amino acid 219, resulting in a Val to Phe substitution (rng-219). Four plasmids (one of which was named pDHK26) had a $\mathrm{G} \rightarrow \mathrm{A}$ transition at the first base pair of the codon for amino acid 248, causing a Glu to Lys substitution ( $r n g-248)$. In the RNase E protein, the amino acids at these two corresponding positions are Ala and Leu, respectively.

To confirm that the observed complementation resulted from these specific amino acid substitutions, we generated pDHK32 (rng-219) and pDHK33 (rng-248) using site-directed mutagenesis of pDHK23. Both of these plasmids behaved identically to the original plasmids (pDHK26) and (pDHK28) with regard to their ability to complement both the rne-1 and rne $\Delta 1018$ alleles and to restore normal 16S rRNA processing in an rng::cat genetic background (data not shown).

\section{Complementation of the growth defect associated with RNase E-deficient strains is dependent on the intracellular level of the Rng-219 and Rng-248 proteins}

Although we did not obtain complementation of rne mutants by overexpressing either the wild-type or N-terminal extended form of RNase $G$, we wanted to rule out that the growth observed in an rne $\Delta 1018$ strain carrying either the $r n g-219$ or the $r n g-248$ allele did not simply result from a further increase in the expression of the mutant RNase G proteins compared with what was obtained with pDHK23 $\left(r n g^{+}\right)$. Western blot analysis demonstrated that cells carrying pDHK23 $\left(r n g^{+}\right)$, pDHK26 (rng-248), or pDHK28 (rng-219) produced comparable levels of RNase G protein (Fig. 1B, lanes 4,5; Table 1).

We next compared the growth properties of strains carrying the $r n g$-219 or $r n g$-248 alleles on either six-to-eight copy (pDHK26 and pDHK28) or single-copy (pDHK29 and pDHK30) number plasmids (Table 2). As a control in these experiments, a strain with the rne $\Delta 645$ allele was included because this truncated RNase E protein supports cell viability at $30^{\circ} \mathrm{C}, 37^{\circ} \mathrm{C}$, and $44^{\circ} \mathrm{C}$ (Ow and Kushner 2002). Although strains containing six-to-eight copies of either the $r n g$-248 (SK3541) or $r n g-219$ (SK3543) mutations grew significantly slower at $37^{\circ} \mathrm{C}$ than strains carrying either the $r n e^{+}$, rne-1, or the rne $\Delta 645$ alleles, the generation times of the $r n e^{+}$, rne $\Delta 645$, rng-219, and $r n g-248$ strains were comparable at $44^{\circ} \mathrm{C}$ (Table 2). Even though all these strains contained an $r n g^{+}$allele on the chromosome, it should be noted that comparable complementation and generation times were obtained when pDHK28 was introduced into an rne $\Delta 1018$ rng::cat double mutant (data not shown).

With the $r n g-219$ and $r n g-248$ alleles on single-copy plasmids, Western blot analysis showed 3.1-fold less RNase $\mathrm{G}$ protein compared with respective plasmids present in sixto-eight copies/cell (Table 1). Under these conditions, the $r n g-219$ and $r n g-248$ alleles still supported cell viability in the rne $\Delta 1018$ genetic background at $30^{\circ} \mathrm{C}$ and $37^{\circ} \mathrm{C}$, but the mutants had significantly longer generation times compared with strains carrying the $r n e^{+}$, rne-1, and rne $\Delta 645$ alleles (Table 2). In addition, the $r n g-219$ and $r n g-248$ strains ceased growing after shift to $44^{\circ} \mathrm{C}$ (Table 2). In fact, the $r n g-219$ strain displayed a more rapid cessation of growth than either the $r n e-1$ or $r n g-248$ strains (data not shown).

Analysis of cell viability showed reproducible differences

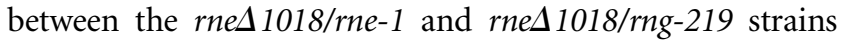
(Fig. 2A). In cultures of the rne $\Delta 1018 / r n g$-219 mutant grown at $30^{\circ} \mathrm{C}$ less than $20 \%$ of the cells formed viable colonies at $30^{\circ} \mathrm{C}$ compared with rne-1 and wild-type strains (Fig. 2A). In fact, when observed under the light microscope, these cultures contained many extremely long multinucleated cells (Fig. 2B). Furthermore, there was actually a 10-fold increase in cell viability in the $r n e \Delta 1018 / r n g-219$ strain for the first $120 \mathrm{~min}$ after the temperature shift (Fig. 2A), accompanied by a significant decrease in the number of elongated cells (Fig. 2B). In contrast, cell viability of the rne $\Delta 1018 /$ rne-1 $^{2}$ strain remained largely unchanged after shift to $44^{\circ} \mathrm{C}$ followed by a gradual decrease after $60 \mathrm{~min}$. It should be noted that elongated cells appeared in the rne-1 strain as had previously be noted by Tamura et al. (2006), but the $r n g$-219 cells appeared smaller in diameter and were more extensively elongated (Fig. 2B). 


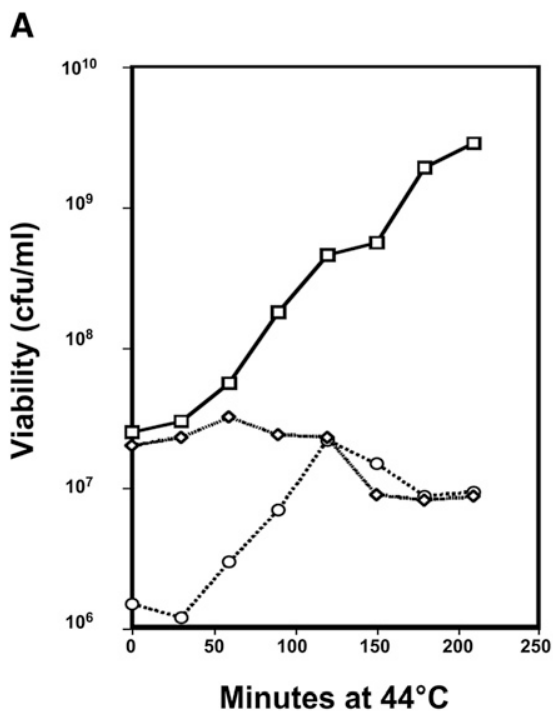

B

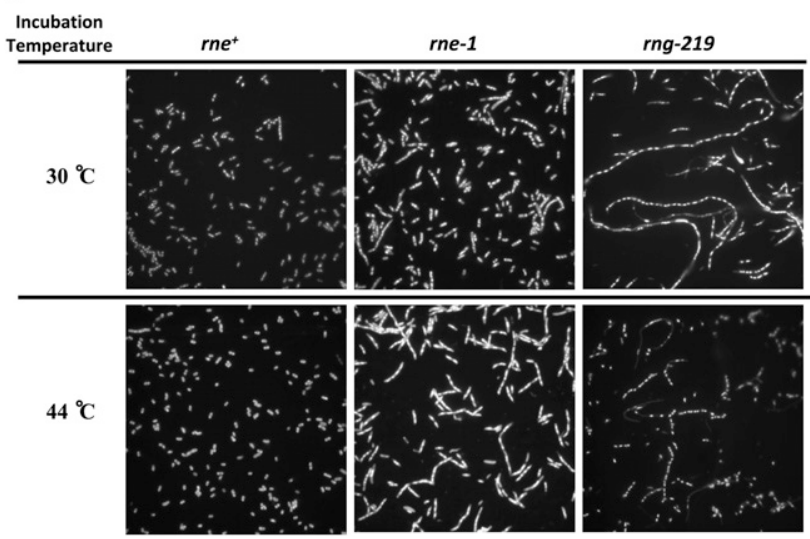

FIGURE 2. Measurement of cell viability and cellular morphology in strains carrying single copies of the $r n e^{+}$(SK10143), rne-1 (SK10144), and $r n g-219$ (SK3564) alleles in an rned 1018 deletion background. $(A)$ Cell viability of $r n e^{+}(\square)$, rne-1 $(\diamond)$, and $r n g-219(\bigcirc)$ was determined as described in Materials and Methods. $(B)$ The $30^{\circ} \mathrm{C}$ cultures were harvested at mid-log phase $\left(1 \times 10^{8}\right.$ cells $\left./ \mathrm{mL}\right)$, while the $44^{\circ} \mathrm{C}$ cultures were harvested $2 \mathrm{~h}$ after the temperature shift. Slides were prepared as described in Materials and Methods.

To provide further support for the hypothesis that the complementation of the rne deletion was dependent on the cellular level of the mutant RNase $G$ proteins, we introduced the $r n g-219$ and $r n g-248$ alleles into the $r n g$ gene (expressed from its own promoter and ribosome binding site) carried on the six-to-eight copy number plasmid pUGK24 (Ow et al. 2003) via site-directed mutagenesis, generating pDHK34 and pDHK35, respectively. Based on Western blot analysis, comparable levels of RNase $G$ were observed with pUGK24 and pDHK34 (Fig. 1C), but these levels represented an approximately sevenfold less RNase G protein compared with the expression from pDHK29 or pDHK30 (Table 1). Furthermore, unlike what was observed with the plasmids pDHK29 and pDHK30, neither pDHK34 nor pDHK35 displaced pSBK1 $\left(r n e^{+}\right)$from SK9714 at either $30^{\circ} \mathrm{C}$ or $37^{\circ} \mathrm{C}$ (Table 1) nor complemented an rne-1 mutant at $44^{\circ} \mathrm{C}$ (data not shown).

\section{pRNG3 and pRNG1200 produce significantly more RNase G protein than either pDHK28 (rng-219) or pDHK26 (rng-248) but support very poor growth in the rne-1 genetic background}

The results described above differed from those of Lee et al. (2002) and Deana and Belasco (2004), who observed growth of RNase E mutants after overexpression of a modified form of RNase G. Accordingly, we transformed pRNG3, which expresses an amino-terminal extended form of RNase G that also has six additional histidines at the carboxy terminus from a lacZ promoter in a plasmid with a pSC101 origin of DNA replication (Lee et al. 2002), pRNG1200, which expresses an amino-terminal extended form of RNase $G$ from a modified RNase G promoter in a pUC plasmid (Deana and Belasco 2004), pDHK11 (rng extended form), pDHK23 ( $r n g$ wildtype), pDHK28 (rng-219), and pDHK26 (rng-248) into the same genetic background (SK6610, rne-1 recA56) in order to compare their ability to support growth at $44^{\circ} \mathrm{C}$ (Fig. 3).

As shown in Figure $3 \mathrm{~B}$, after $24 \mathrm{~h}$ at $44^{\circ} \mathrm{C}$ there was no growth in the rne-1 control or rne-1 transformants carrying either pDHK11 or pDHK23. In strains carrying either rng219 (pDHK28) or $r n g-248$ (pDHK26) allele uniform growth was obtained (Fig. 3B). In contrast, very spotty growth was observed with both pRNG1200 and pRNG3 in the presence of $100 \mu \mathrm{M}$ IPTG. After $48 \mathrm{~h}$ at $44^{\circ} \mathrm{C}$ some additional spotty growth was observed with pRNG3, but it was still much less than obtained with either pDHK28 (rng-219) or pDHK26 (rng-248) (Fig. 3B). No further improvement was observed with pRNG1200 after $48 \mathrm{~h}$ (Fig. 3B).

Western analysis of RNase $\mathrm{G}$ protein levels in the various strains showed that the $r n e-1 / \mathrm{pDHK} 11$, rne-1/pDHK23, and rne-1/pDHK28 strains had comparable levels of RNase G protein (Fig. 1B; Table 1). In contrast, the total amount of protein loaded from rne-1/pRNG3 (in the presence of 100 $\mu \mathrm{M}$ IPTG) and the rne-1/pRNG1200 strains had to be reduced two- and 20 -fold, respectively, to avoid overloading the gel (Fig. 1B). Taken together, the data in Figure 1B and Table 1 indicated that there was 174- and 1440-fold more RNase G, respectively, in the pRNG3- and pRNG1200containing strains compared with the level of protein found in a wild-type cell.

\section{Both amino acid changes are located within the predicted RNase $\mathbf{H}$ domain of RNase $\mathbf{G}$}

The solution of the crystal structure of the catalytic region of RNase E identified five distinguishable subdomains within the catalytic portion of the protein $\left(5^{\prime}\right.$ sensor, S1 RNA binding region, RNase $\mathrm{H}$ and DNase I domains and a $\mathrm{Zn}$ link) (Callaghan et al. 2005). Based on the overall 34.1\% 
(A)

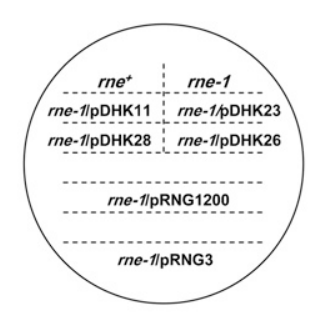

(B)

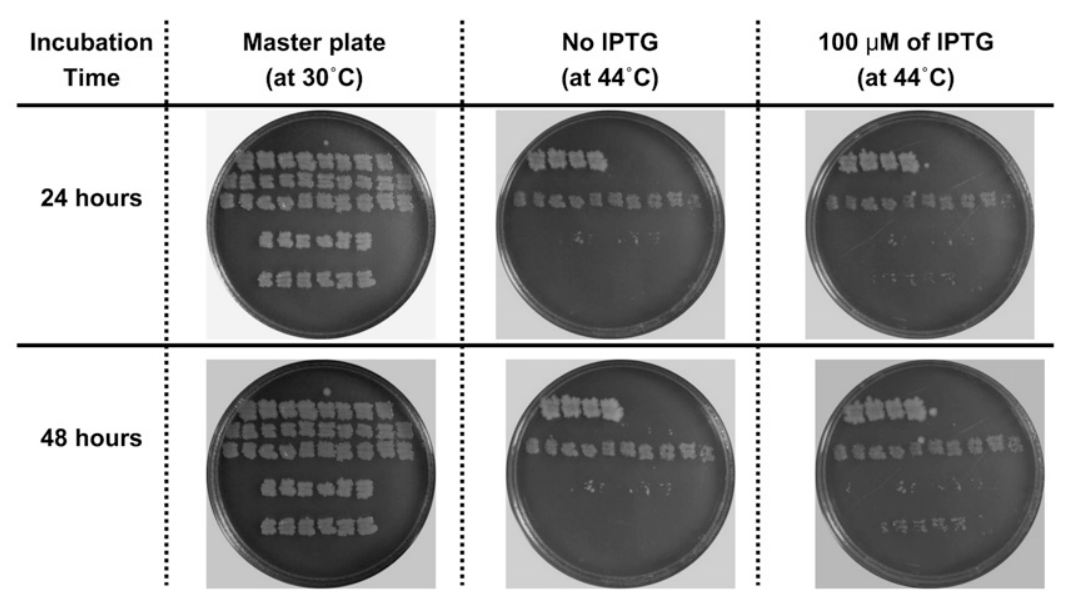

FIGURE 3. Comparison of the growth properties of an rne-1 strain carrying various $r n g$ plasmids. Individual colonies of the various strains as indicated in $A$ were patched onto a Luria agar master plate and grown overnight at $30^{\circ} \mathrm{C}(B)$. Replicas were made and incubated for either 24 or $48 \mathrm{~h}$ at $44^{\circ} \mathrm{C}(B)$.

sequence identity between RNase G and RNase E proteins within the catalytic region, we used Geno 3D (http://geno3dpbil-ibcp.fr), an online homology modeling program (Combet et al. 2002) to predict the 3D structure for RNase G (Fig. $4 \mathrm{~B})$. This analysis showed that RNase $\mathrm{G}$ can be folded, with a high degree of certainty, into the same five distinctive subdomains as RNase E (Fig. 4A). Of the five subdomains, the predicted catalytic site contained within the DNase I domain was the most structurally conserved region $(45.5 \%$ sequence identity), while the RNase $\mathrm{H}$ region showed the most divergence (26.6\% sequence identity) (Fig. 4A,B). Interestingly, both the $r n g-219$ and $r n g-248$ mutations occurred in the predicted RNase H domain. Detailed analysis of the mutationally altered RNase $\mathrm{H}$ domains showed very subtle changes in the side chains extending from two distinct $\alpha$-helices associated with the RNase $\mathrm{H}$ domain in the two RNase $G$ mutants (Fig. 5A,B). Since the mutations lie close to the $5^{\prime}$ sensor domain, it is possible that they lead to a modification of its activity.

\section{Domain swaps between RNase E and RNase G generate proteins that do not complement RNase E deficiency}

Based on the high degree of predicted structural similarity between RNase E and RNase G (Fig. 4), we hypothesized that a domain swapping approach, as successfully used with poly(A) polymerase and tRNA nucleotidyltransferase (Betat et al. 2004), might help distinguish important features of these two paralogs. To test this idea directly, we made three chimeric constructs: amino acids 213-281 of the RNase $\mathrm{H}$ domain in RNase G were replaced with the same region derived from RNase E; amino acids 1-280 of RNase $G$ were replaced by the $\mathrm{S} 1$ binding region, $5^{\prime}$ sensor region and the entire RNase $\mathrm{H}$ domain from RNase E; and amino acids 280489 of RNase $G$ were replaced with the DNase I domain and Zn-link from RNase E (amino acids 280-418). While all three chimeric proteins were expressed at levels comparable to those observed with pDHK26 and pDHK28 (data not shown), none of them complemented either the rne-1 or rne $\Delta 1018$ alleles, improved the maturation of $5 \mathrm{~S}$ rRNA, or converted the $16.3 \mathrm{~S}$ rRNA precursor observed in an rng::cat mutant into its mature $16 \mathrm{~S}$ form (data not shown).

\section{The Rng-219 and Rng-248 proteins effectively restore $9 \mathrm{~S}$ rRNA processing at $44^{\circ} \mathrm{C}$}

RNase E was initially discovered based on its role in the maturation of the 9S rRNA precursor into a functional $5 \mathrm{~S}$ rRNA (Apirion and Lasser 1978). Subsequent analysis of this reaction showed that while rne-1 mutants were quite defective in 9S rRNA maturation (Ow et al. 2000), truncated RNase E proteins cleaved this substrate quite efficiently (Lopez et al. 1999; Ow et al. 2000). Furthermore, increased levels of wild-type RNase $G$ partially restored $9 S$ rRNA maturation in an rne-1 mutant at $44^{\circ} \mathrm{C}$ (Ow et al. 2003). We observed that in strains carrying the various rne and $r n g$ alleles in six-to-eight copies/cell, the processed fractions ([PFs], defined as the fraction of mature $5 \mathrm{~S}$ rRNA relative to all $5 \mathrm{~S}$ rRNA containing species) of $5 \mathrm{~S}$ rRNA at $30^{\circ} \mathrm{C}$ were nearly identical in the wild-type, rne-1, and rne $\Delta 645$ strains (Fig. 6A, lanes 1-3) in agreement with previous results (Ow and Kushner 2002). However, the PF was reduced to $\sim 0.70$ in the $r n g-219$ and $r n g-248$ mutants (Fig. 6A, lanes 4,5). Upon shift to $44^{\circ} \mathrm{C}$, the $\mathrm{PF}$ in the rne-1 strain decreased to 0.48 (Fig. 6A, lane 7), while the PF in the $r n g-248$ and $r n g-219$ alleles increased to 0.82 and 0.84 (Fig. 6A, lanes 9,10), respectively.

When the experiment was performed with strains carrying either the $r n g-219$ or $r n g-248$ alleles in single copy, 9S rRNA maturation in the two rng mutants was comparable 


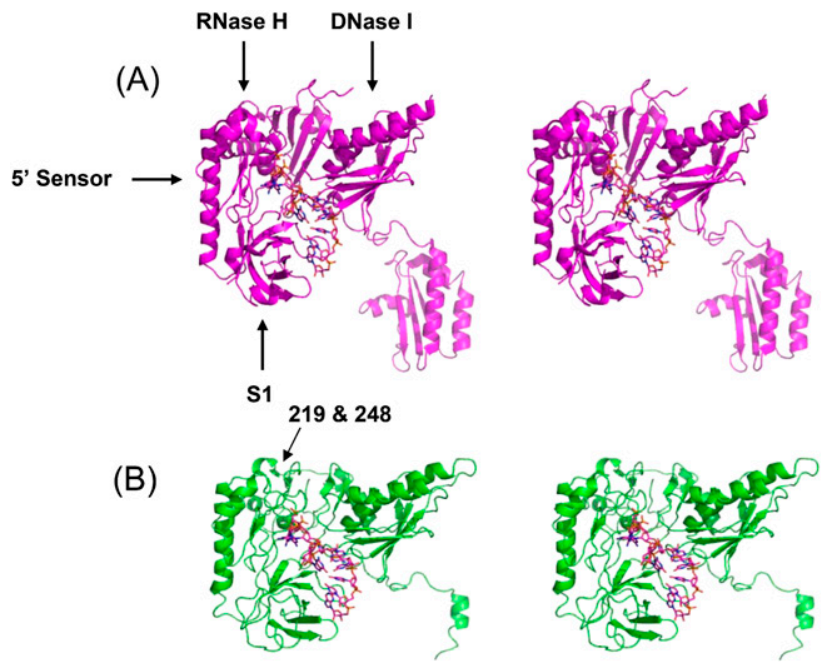

FIGURE 4. Stereo views of the crystal structure of the catalytic domain of E. coli RNase $\mathrm{E}$ and the predicted structure of its homolog RNase G. $(A)$ The $3 \mathrm{D}$ ribbon structure of the catalytic domain of RNase $\mathrm{E}$ is based on the coordinates published by Callaghan et al. (2005). (B) The predicted structure of E. coli RNase G bound to RNA as described in Materials and Methods. The RNA is shown in stick representation. Figures are prepared in PyMOL. The S1, 5' sensor, RNase $\mathrm{H}$, and DNase I subdomains are indicated as well as the approximate locations of the $r n g-219$ and $r n g-248$ alleles.

at both $30^{\circ} \mathrm{C}$ and $44^{\circ} \mathrm{C}$ (Fig. $6 \mathrm{~B}$, lanes $14,15,19,20$ ), even though the cells ceased growing at the elevated temperature. Interestingly, the PFs of the two rng mutants were more than twofold higher compared with what was observed with the rne-1 strain at $44^{\circ} \mathrm{C}$ (Fig. 6B, lanes 17,19,20). In all cases, the pattern of processing intermediates obtained in the rne-1, $r n g-219$ and $r n g-248$ strains was nearly identical (Fig. 6A,B) and generally agreed with the results of Lee et al. (2002).

\section{The absence of RNase E differentially affects the decay of specific mRNAs}

Although experiments using various rne alleles (i.e., rne-1, rne-131, rne $\Delta 610$, and rne $\Delta 645$ ) have shown that the decay of specific mRNAs is initiated by RNase E (Mackie 1991; Hajnsdorf and Regnier 1999; Ow et al. 2000; Celesnik et al. 2007), recent work has suggested that both RNase G and RNase $\mathrm{Z}$ can also participate in the decay of selected transcripts (Umitsuki et al. 2001; Wachi et al. 2001; Kaga et al. 2002; Lee et al. 2002; Ow et al. 2003; Perwez and Kushner 2006). In addition, rne-1 strains retain a significant amount of residual RNase $\mathrm{E}$ activity at $44^{\circ} \mathrm{C}$ (Mohanty and

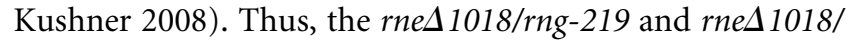
rng-248 strains provided a means to test if the initiation of endonucleolytic decay of specific mRNAs was absolutely dependent on the presence of RNase E. For our analysis, we determined the half-lives of four mRNAs previously demonstrated to decay in an RNase E-dependent fashion ( $r p s O$, $r p s T, \operatorname{csp} A$, and $\operatorname{csp}$ E) (Mackie 1991; Hajnsdorf et al. 1994; Perwez and Kushner 2006; Hankins et al. 2007). In agree- ment with previously published results (Ow et al. 2000, 2003), the half-lives of all four transcripts were significantly longer in the rnes1018/rne-1 strain when the rne-1 allele was present in either six-to-eight copies/cell or single copy/ cell (Table 3).

Strikingly different results were obtained for the four mRNAs in strains carrying the $r n g-219$ and $r n g-248$ alleles in six-to-eight copies/cell. The half-lives of the $r p s O$ and $\operatorname{csp} A$ transcripts increased dramatically between two- and 12-fold compared with the rne-1 strain and were directly correlated to the amount of altered RNase $G$ protein present in the cell (Table 3). These results showed that both the $r p s O$ and $\operatorname{csp} A$ transcripts were highly dependent on RNase E for their decay and were not efficiently cleaved by either mutant RNase G protein. However, in the rne $\Delta 1018 / r n g-219$ and rne $\Delta$ 1018/rng-248 mutants numerous decay intermediates of cspA were present that were not observed in the rnes 1018/ rne-1 strain (data not shown). It should be noted that the half-life of the $\operatorname{csp} A$ mRNA obtained here in wild-type E. coli (1-2 min) (Table 3) was significantly longer than has been reported previously (Goldenberg et al. 1996; Hankins et al. 2007).

In contrast with what was observed with $r p s O$ and $\operatorname{csp} A$, the $\operatorname{rps} T$ and $c s p E$ mRNAs had comparable half-lives in the rne-1, rng-219, and $r n g-248$ strains when the alleles were present either in single copy/cell or six-to-eight copies/cell

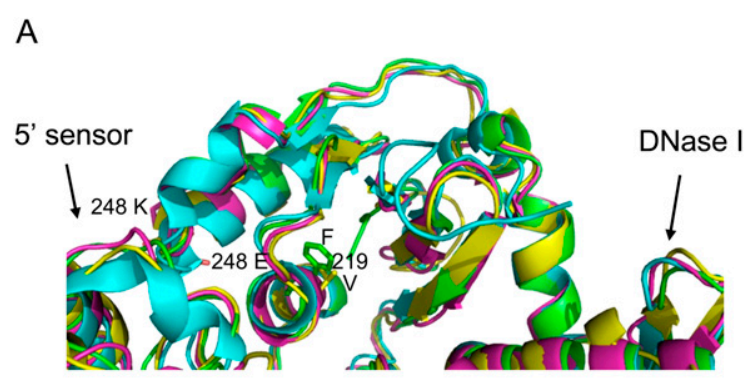

B

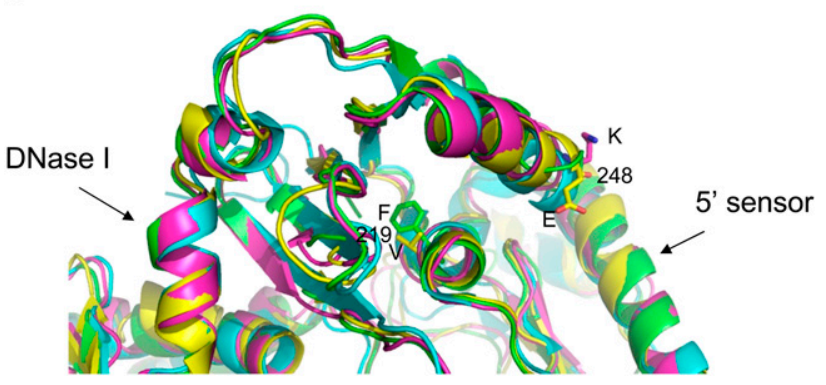

FIGURE 5. Expanded view of the RNase $\mathrm{H}$ subdomain of the RNase E, RNase G, Rng-219, and Rng-248 proteins. The structures were prepared as described in Materials and Methods and are viewed in PyMOL. The adjacent $5^{\prime}$ sensor and DNase I subdomains are indicated. (A) Top view. (B) Bottom view. Cyan, RNase E; yellow, model of RNase G; green, model of Rng-219; and magenta, model of Rng-248. 
(A)

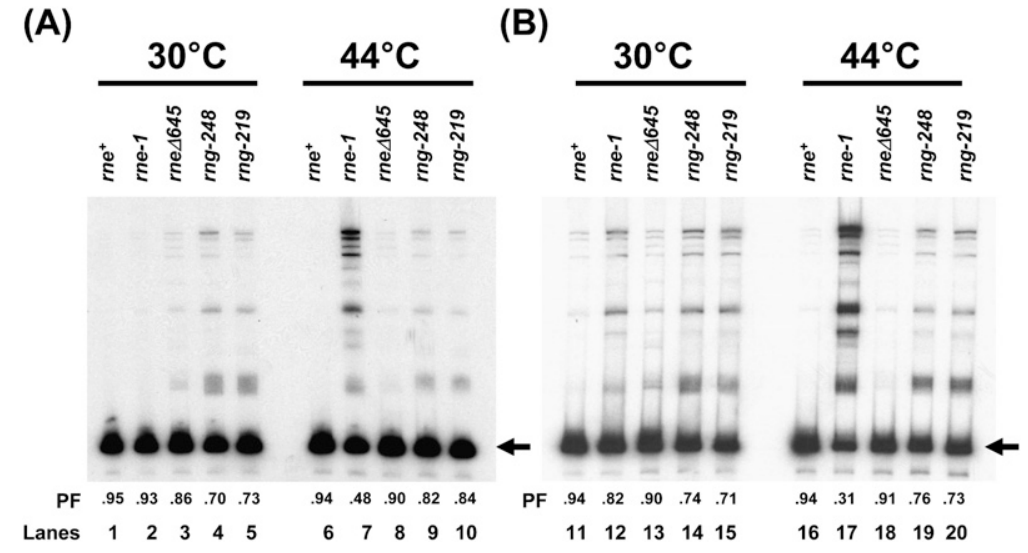

FIGURE 6. Analysis of $9 S$ rRNA processing. Equivalent amounts $(5 \mu \mathrm{g})$ of total steady-state RNA extracted from cultures that either had been grown at $30^{\circ} \mathrm{C}$ or had been shifted to $44^{\circ} \mathrm{C}$ for $120 \mathrm{~min}$, as described in Materials and Methods, were separated in a $6 \%$ polyacrylamide/7 $\mathrm{M}$ urea gel and electroblotted onto a Biotrans ${ }^{+}$membrane. The membrane was probed with ${ }^{32} \mathrm{P}$-end-labeled oligonucleotide complementary to the mature 5S rRNA (PB5S; Babitzke and Kushner 1991). The left arrows indicate the mature 5S rRNA. (A) rne and rng alleles present in six-to-eight copies/cell. SK9714 (rne $\left.{ }^{+}\right)$, SK9937 (rne-1), SK9987 (rned645), SK3541 (rng-248), and SK3543 $(r n g-219)$. (B) rne and $r n g$ alleles present in single copy/cell. SK10143 $\left(r n e^{+}\right)$, SK10144 (rne-1), SK2685 (rned645), SK3563 (rng-248), and SK3564 (rng-219). PF denotes the processed fraction, which is defined as the amount of mature 5S rRNA divided by the total amount of the 5S rRNA (processed and unprocessed).

(Table 3). For example, the half-life of the $\operatorname{rps} T_{\mathrm{P} 1}$ transcript

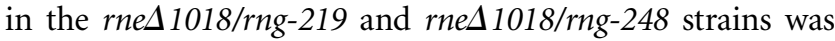
2.6 and $2.7 \mathrm{~min}$, respectively, when the alleles were present in either six-to-eight copies/cell compared with $8.9 \mathrm{~min}$, which was observed in an rne-1 rng::cat double mutant (Ow et al. 2003). This result indicated that both mutant RNase G proteins were able to substitute, relatively effectively, for RNase $\mathrm{E}$ at least in the initiation of the decay of the fulllength mRNA. This idea was supported by the presence of major new rpsT decay intermediates in the $r n g$-219 and $r n g$ 248 strains that were not present in either wild-type or $r n e-1$ strains (data not shown). Even when the $r n g-219$ and $r n g$ 248 alleles were present in single copy, the $r p s T_{\mathrm{P} 1}$ transcript half-life (between 6 and $7 \mathrm{~min}$ ) (Table 3) was still shorter than that observed in the rne-1 rng::cat double mutant (Ow et al. 2003).

\section{The maturation of $\operatorname{tRNA}^{\mathrm{Cys}}$, $\mathrm{tRNA}^{\mathrm{His}}$, and tRNA ${ }^{\text {Pro }}$ but not tRNA ${ }^{\text {Asn }}$ is completely dependent on RNase $E$}

RNase $\mathrm{E}$ is critical for the initial processing of many tRNA precursors in E. coli (Ray and Apirion 1981; Li and Deutscher 2002; Ow and Kushner 2002). In fact, the essential function of RNase $\mathrm{E}$ was suggested to involve its role in the initiation of tRNA maturation ( $\mathrm{Li}$ and Deutscher 2002; Ow and Kushner 2002; Perwez et al. 2008), although Deana and Belasco (2004) have challenged this hypothesis. However, all the published experiments examining the role of RNase $\mathrm{E}$ in tRNA maturation have been carried out using strains that

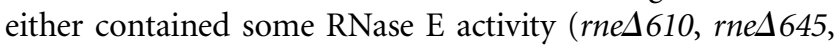
or rne under the control of a lac promoter) or retained re- sidual activity at the nonpermissive temperature (rne-1 and rne-3071) (Mohanty and Kushner 2008). Since the rned1018/ rng-219 and rned1018/rng-248 mutants contained no RNase E activity, we compared the processing of four selected tRNA species $\left(\mathrm{tRNA}^{\mathrm{His}}\right.$, $\mathrm{tRNA}^{\text {Pro }}, \mathrm{tRNA}^{\mathrm{Cys}}$, and $\left.\mathrm{tRNA}^{\mathrm{Asn}}\right)$. As an internal control we included the rne 645 allele, since this truncated RNase $\mathrm{E}$ protein supports cell viability at both $30^{\circ} \mathrm{C}$ and $44^{\circ} \mathrm{C}$ (Ow and Kushner 2002). tRNA $^{\text {His }}$, tRNA $^{\text {Cys }}$, and $\mathrm{tRNA}^{\text {Pro }}$ were chosen because their maturation is highly dependent on RNase E (Li and Deutscher 2002; Ow and Kushner 2002). In contrast, $\mathrm{tRNA}^{\text {Asn }}$ was included because each of its four precursors appeared to be processed relatively efficiently in rne-1 mutants (Ow and Kushner 2002).

tRNA maturation was first tested with $r n e^{+}$, rne-1, rne $4645, r n g-219$, and rng-248 alleles present on a single-copy plasmid in a rned 1018 deletion strain (Fig. 7A-D). The efficiency of tRNA maturation was quantified by determining the $\mathrm{PF}$ of mature tRNA relative to the total amount of processed and unprocessed species. Interestingly, at $30^{\circ} \mathrm{C}$, a condition where all the strains were viable, the PF values of all four tRNA species were two- to 10-fold lower in the $r n g-219$ and $r n g-$ 248 mutants than in the $r n e^{+}$, rne $\Delta 645$, and rne-1 strains (Fig. 7A-D; Table 4). This observation may help explain the much slower growth rates observed in these strains at $30^{\circ} \mathrm{C}$ (Table 2). Furthermore, the processing of $\mathrm{tRNA}^{\mathrm{His}}$, $\mathrm{tRNA}^{\mathrm{Cys}}$, and tRNA ${ }^{\text {Pro }}$, as expected, was more dramatically affected than that of tRNA ${ }^{\text {Asn }}$. For example, compared to the wildtype control, the PF of $\mathrm{tRNA}^{\mathrm{His}}(0.05)$ decreased over 10fold in the $r n g-219$ and $r n g-248$ strains at $30^{\circ} \mathrm{C}$ (Fig. 7A; Table 4) compared with only an approximately twofold reduction for tRNA ${ }^{\text {Asn }}$ (Fig. 7C; Table 4).

In experiments carried out after a 2 -h shift to $44^{\circ} \mathrm{C}$, the $\mathrm{PF}$ values of all four tRNAs decreased significantly in the rne-1 strain compared with the wild-type and rne 4645 controls (Fig. 7A-D; Table 4). In contrast, the PF values for all four tRNA species increased 1.3-2.2-fold in the rng-219 and rng248 strains compared with what was observed at $30^{\circ} \mathrm{C}$ but were still less than or equal to those obtained with the $r n e-1$ allele (Fig. 7A-D; Table 4).

When the experiments were repeated with each allele present in six-to-eight copies/cell, the efficiency of tRNA maturation in the $r n e-1, r n g-219$, and $r n g-248$ strains improved 1.2-2.0-fold for all four tRNA species at $30^{\circ} \mathrm{C}$ and $44^{\circ} \mathrm{C}$ compared with what was observed when the alleles were present in single copy (Fig. 7; Table 4). However, in all cases except for tRNA ${ }^{\text {Pro, }}$, the PF values in the $r n g-219$ and $r n g$-248 strains at $44^{\circ} \mathrm{C}$ were significantly less than in the 
TABLE 3. Half-lives of mRNAs in various strains

\begin{tabular}{|c|c|c|c|c|}
\hline \multirow[b]{2}{*}{ Genotype } & \multicolumn{4}{|c|}{ Half-life $(\mathrm{min})^{\mathrm{a}}$} \\
\hline & $r n e^{+}$ & rne-1 & $r n g-248$ & rng-219 \\
\hline \multicolumn{5}{|c|}{ Alleles present in six-to-eight copies/cell } \\
\hline \multicolumn{5}{|c|}{ Transcript } \\
\hline$r p s O_{\mathrm{P} 1-\mathrm{RIII}}$ & $0.9 \pm 0.1$ & $1.2 \pm 0.1$ & $13.9 \pm 0.5$ & $13.7 \pm 3.0$ \\
\hline rpsOP1-t1 & $1.4 \pm 0.2$ & $5.5 \pm 0.5$ & $16.8 \pm 2.0$ & $16.8 \pm 2.0$ \\
\hline $\operatorname{rps} T_{\mathrm{P} 1}$ & $1.5 \pm 0.2$ & $4.6 \pm 0.6$ & $2.6 \pm 0.3$ & $2.7 \pm 0.1$ \\
\hline$r p s T_{\mathrm{P} 2}$ & $1.8 \pm 0.1$ & $2.5 \pm 0.6$ & $2.4 \pm 0.2$ & $2.4 \pm 0.1$ \\
\hline $\operatorname{csp} A$ & $1.1 \pm 0.1$ & $2.0 \pm 0.2$ & $3.8 \pm 0.6$ & $4.3 \pm 0.3$ \\
\hline $\operatorname{csp} E$ & $1.1 \pm 0.1$ & $13.1 \pm 0.1$ & $10.3 \pm 2.4$ & $9.8 \pm 0.6$ \\
\hline \multicolumn{5}{|c|}{ Alleles present in single copy/cell } \\
\hline$r p s O_{\mathrm{P} 1-\mathrm{RIII}}$ & $1.2 \pm 0.2$ & $2.0 \pm 0.3$ & $17.2 \pm 2.0$ & $21.2 \pm 3.8$ \\
\hline$r p s O_{\mathrm{P} 1-\mathrm{t} 1}$ & $2.6 \pm 0.2$ & $10.0 \pm 2.0$ & $>30$ & $>30$ \\
\hline$r p s T_{\mathrm{P} 1}$ & $1.6 \pm 0.2$ & $7.6 \pm 0.9$ & $7.0 \pm 1.0$ & $6.6 \pm 0.9$ \\
\hline$r p s T_{\mathrm{P} 2}$ & $1.9 \pm 0.4$ & $5.6 \pm 0.4$ & $5.6 \pm 0.4$ & $6.2 \pm 0.9$ \\
\hline $\operatorname{csp} A$ & $2.2 \pm 0.2$ & $4.6 \pm 0.5$ & $9.6 \pm 1.5$ & $11.4 \pm 0.6$ \\
\hline $\operatorname{csp} E$ & $2.4 \pm 0.2$ & $10.4 \pm 1.2$ & $14.5 \pm 2.5$ & $13.2 \pm 1.2$ \\
\hline
\end{tabular}

In all of these strains, the chromosomal copy of the rne gene has been deleted (rnes 1018) and the alleles indicated are present on either a six-to-eight copy number plasmid or a single-copy plasmid. All mRNA half-lives were measured immediately after shift to $44^{\circ} \mathrm{C}$ as described in Materials and Methods. Each strain carries an rne $\Delta 1018$ allele on the chromosome. The $r p s O_{\mathrm{P} 1-\mathrm{RIII}}$ and $r p s O_{\mathrm{P} 1-t 1}$ transcripts are those described by Hajnsdorf et al. (1996). The $r p s T_{\mathrm{P} 1}$ and $r p s T_{\mathrm{P} 2}$ represent transcripts from the gene's two promoters (Mackie 1991).

${ }^{a}$ Represents the average of at least four independent determinations.

rne-1 strain (Table 4, cf. 0.56 for $\mathrm{tRNA}^{\mathrm{Cys}}$ in the rne-1 strain and 0.20 in either $r n g$ mutant), even though under these conditions the $r n g-219$ and $r n g-248$ strains were viable, while the rne-1 mutant was not.

\section{DISCUSSION}

The results reported here demonstrate that even when intracellular RNase G levels were increased $\sim 30$-fold by employing pDHK23 (Table 1; Fig. 1), the native protein did not support cell viability at $44^{\circ} \mathrm{C}$ in an rne-1 genetic background (Fig. 3). Furthermore, not withstanding previous reports that six extra amino acids at the amino terminus of RNase G (a situation that does not occur in vivo) (Briant et al. 2003) led to complementation of RNase E mutants (Lee et al. 2002; Deana and Belasco 2004), this modified protein did not effectively complement the rne-1 allele at $44^{\circ} \mathrm{C}$ in the MG1693 genetic background (Fig. 3).

Furthermore, the data from Figures $1 \mathrm{~B}$ and 3 and Table 1 clearly distinguish the results described here and the experiments of Lee et al. (2002) and Deana and Belasco (2004). First, both pRNG3 (Lee et al. 2002) and pRNG1200 (Deana and Belasco 2004) led to the synthesis of between five- and 39-fold more RNase G protein, respectively, than was observed with either pDHK23 $\left(r n g^{+}\right)$or pDHK28 (rng-219) (Fig. 1B; Table 1), resulting in intracellular levels of wild-type RNase $G$ that were five- to 43-fold higher than normal physiological levels of RNase E (Table 1). Yet even under these conditions, the N-terminal extended form of RNase G only weakly supported cell growth of an rne-1 strain at $44^{\circ} \mathrm{C}$ compared with the Rng-219 and Rng-248 proteins (Fig. 3). In contrast, when the N-terminal extended form of RNase G was expressed at levels comparable to either Rng-219 or Rng248 (Table 1), no growth at $44^{\circ} \mathrm{C}$ was observed (Fig. 3).

Since DNA sequencing of the pRNG3 and pRNG1200 plasmids did not reveal any rng mutations (data not shown), it appears that the weak cell growth observed with pRNG3 and pRNG1200 at $44^{\circ} \mathrm{C}$ (Fig. 3) arose primarily from the very high levels of RNase $G$, which led to the survival of enough cells to form very small colonies. We hypothesize that if there is enough RNase $G$ in a cell lacking RNase E, a small fraction of cells can survive as a result of inefficient processing by RNase $\mathrm{G}$ of whatever RNA species may be essential for cell survival. In contrast, the complementation of the rne $\Delta 1018$ and rne-1 alleles observed with the rng-219and $r n g$-248-encoded RNase G occurred over a range of mutant protein concentrations that were less than or equal to the normal physiological level of RNase E on a molecule/ molecule basis (Table 1), suggesting a functional alteration in the activity of the two mutant RNase G proteins.

While it was surprising that subtle changes in the predicted RNase $\mathrm{H}$ domain of RNase $\mathrm{G}$ - a region with the least apparent 3D similarity to RNase E (Figs. 4, 5) -led to proteins that complemented the loss of RNase E, this result indicates that at least some of the biological differences between the two enzymes are related to this domain. These mutants suggest a possible important role for the RNase $\mathrm{H}$ subdomain in the activity of both proteins. In fact, we have recently isolated temperature-sensitive rne mutations that map in the RNase H domain (J Reyes-Darius, T Perwcz, and SR Kushner, in prep.). Whether the $\mathrm{RNase} H$ domain is critical for initial binding of various RNA molecules or is involved in promoting phosphodiester bond cleavages remains to be determined.

Although the experiments reported here do not provide a definitive explanation for the differences in the catalytic activities of RNase E and RNase G, the ability of the altered Rng proteins to support cell viability in an rne deletion strain at protein levels less than or comparable to those observed for RNase E (Table 1) in wild-type cells did provide an opportunity to critically examine the role of RNase $\mathrm{E}$ in $9 \mathrm{~S}$ rRNA processing, mRNA decay, and tRNA maturation.

For example, since the half-life of the $r p s O$ transcript increased dramatically in the complete absence of RNase E (Table 3) and no decay intermediates were observed (data not shown), it would appear that this mRNA is normally not a substrate for RNase Z (Perwez and Kushner 2006), RNase LS (Otsuka and Yonesaki 2005), or RNase G. Although there might be some concern that the Rng-219 and Rng248 proteins could have a dominant negative phenotype, as has been observed with certain RNase E mutants (Briegel et al. 2006), their ability to support cell viability in an rne 1018 rng::cat double mutant (data not shown) suggests that this is not the case. The results with both the $\operatorname{rps} O$ 
(A) tRNA ${ }^{\text {His }}$

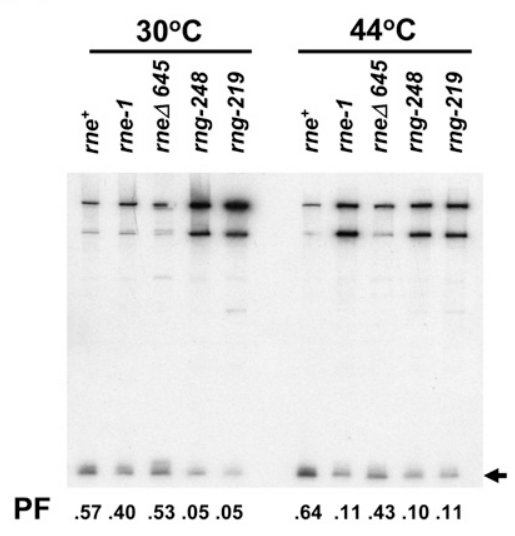

(C) tRNA ${ }^{\text {Asn }}$

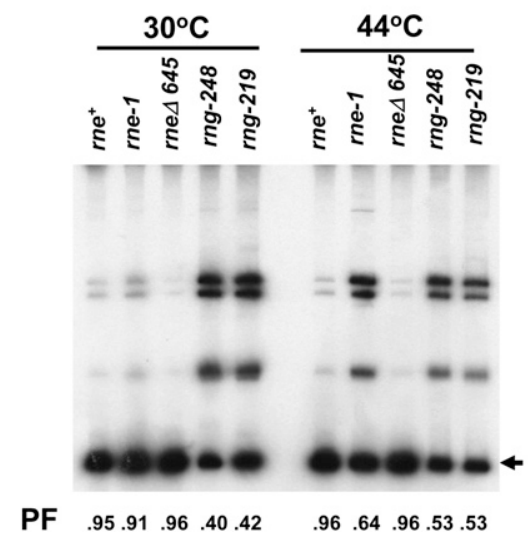

(B) tRNA ${ }^{\text {Pro }}$

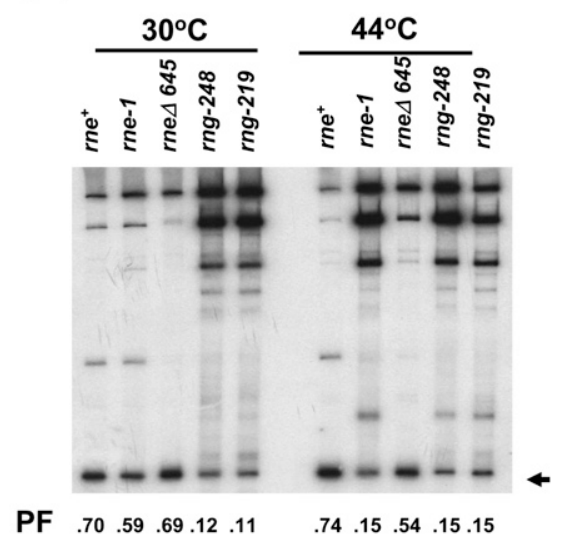

(D) tRNACys

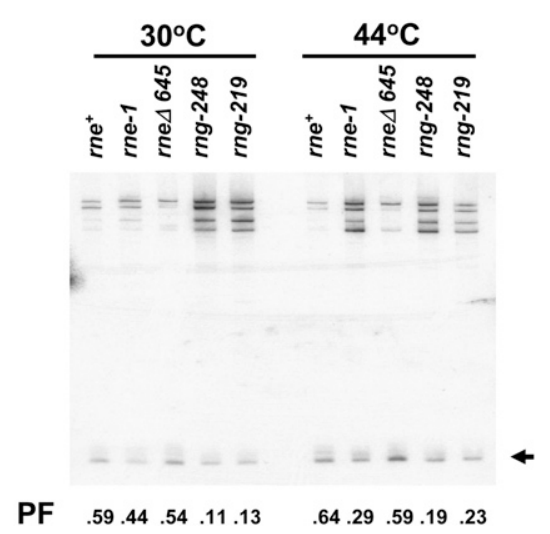

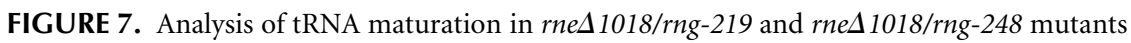
when the $r n g$ alleles were present in single copy. Steady-state RNA $(5 \mu \mathrm{g} / \mathrm{lane})$ isolated from cultures grown either at $30^{\circ} \mathrm{C}$ or after shift to $44^{\circ} \mathrm{C}$ was analyzed as described in Materials and Methods. PF denotes the processed fraction, which is defined as the amount of a given mature tRNA divided by the total amount of tRNA transcribed. The numbers represent the average of three to four independent determinations. The standard deviations from the mean are presented in Table 4. Arrows in the right margins indicate the position of each mature tRNA. RNA levels were normalized as described in Materials and Methods.

and $\operatorname{csp} A$ mRNAs also indicate that the Rne-1 protein retains a significant amount of residual activity at the nonpermissive temperature, a conclusion also supported by the analysis of tRNA processing by Mohanty and Kushner (2008).

In contrast, the half-lives of the $r p s T$ ( $r p s T_{\mathrm{P} 1}$ and $\left.r p s T_{\mathrm{P} 2}\right)$ and $\operatorname{csp} E$ transcripts did not change significantly among the

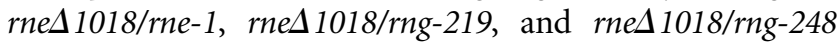
strains under any condition tested (Table 3 ), supporting previous results that other ribonucleases such as RNase $G$ and RNase $\mathrm{Z}$ can initiate the decay of these transcripts (Ow et al. 2003; Perwez and Kushner 2006). Furthermore, the change in the decay pattern of the rpsT transcripts in the $r n e \Delta 1018$ / rng-219 and rnes1019/rng-248 strains (data not shown) demonstrated that the altered RNase G proteins probably cleaved the transcripts at locations different from those recognized by RNase E. In fact, in vitro studies show that RNase
E and RNase G show little, if any, overlap in their cleavage specificity of the $\operatorname{rps} T_{\mathrm{P} 1}$ transcript (D-H Chung and SR Kushner, in prep.). Thus, it appears that some mRNAs ( $r p s O$ and $\operatorname{csp} A$ ) are much more dependent on RNase $\mathrm{E}$ for their decay than others (rpsT and cspE) (Table 3).

The data on tRNA processing were of equal interest. While RNase E is clearly required for the initial processing of many tRNAs in vivo ( $\mathrm{Li}$ and Deutscher 2002; Ow and Kushner 2002), it cleaves some tRNA precursors more efficiently than others (Ow and Kushner 2002). The results presented in Figure 7 and Table 4 confirm that for some tRNAs (notably tRNA $^{\text {His }}$, tRNA ${ }^{\text {Pro }}$, and tRNA ${ }^{\text {Cys }}$ ) initial processing of the polycistronic transcripts containing these species appears to be absolutely dependent on RNase E under normal physiological conditions. For example, when the $r n g-219$ and $r n g-248$ alleles were present on single-copy plasmids, the PFs of these three tRNAs at $30^{\circ} \mathrm{C}$ were $0.05-0.13$ (Fig. 7; Table 4). When the level of the mutant RNase $G$ proteins was increased $\sim 3.2$-fold (Table $1)$, the processed fractions only increased marginally to between 0.10 and 0.21 at the same temperature (Table 4). These data indicate that the small amount of these three tRNAs arising in the RNase E deletion mutant arose from very inefficient processing carried out by the Rng-219 and Rng-248 proteins. Thus, it appears that RNase E is absolutely required to carry out the initial processing of the polycistronic operons that contain tRNA ${ }^{\text {His, }}$ tRNA ${ }^{\text {Cys }}$, and tRNA ${ }^{\text {Pro }}$.

Finally, it is important to note that the RNase G mutants described here support cell growth in the absence of RNase $\mathrm{E}$, but the altered proteins only partially substitute for its functions in mRNA decay and only marginally, if at all, participate in tRNA processing (Figs. 5, 7; Tables 3, 4). Thus it is still not clear at this time what constitutes the essential function of RNase E. In addition, the data on tRNA processing shown in Figure 7 and Table 4 demonstrate that cells can grow, albeit slowly (Table 2), with only a very small fraction of their normal complement of functional tRNAs. Taken together, it would appear that very small changes in either the availability of a processed structural RNA or the level of a particular mRNA probably accounts for the difference between a viable or inviable cell. The current assays being used to measure differences in the levels of various RNA species may simply not be sensitive enough to identify 
TABLE 4. Processed fractions for tRNA maturation experiments

\begin{tabular}{|c|c|c|c|c|c|}
\hline \multirow[b]{2}{*}{ Species } & \multicolumn{5}{|c|}{ Allele } \\
\hline & $r n e^{+}$ & rne-1 & rne $\Delta 645$ & $r n g-219$ & $r n g-248$ \\
\hline \multicolumn{6}{|c|}{ Alleles present in single copy $\left(30^{\circ} \mathrm{C}\right)$} \\
\hline tRNA ${ }^{H i s}$ & $0.57 \pm 0.11$ & $0.40 \pm 0.1$ & $0.53 \pm 0.13$ & $0.05 \pm 0.01$ & $0.05 \pm 0.0$ \\
\hline tRNA ${ }^{\text {Pro }}$ & $0.70 \pm 0.13$ & $0.59 \pm 0.14$ & $0.69 \pm 0.12$ & $0.12 \pm 0.03$ & $0.11 \pm 0.02$ \\
\hline tRNA ${ }^{\text {Asn }}$ & $0.95 \pm 0.03$ & $0.91 \pm 0.02$ & $0.96 \pm 0.01$ & $0.40 \pm 0.05$ & $0.42 \pm 0.04$ \\
\hline tRNA ${ }^{\text {Cys }}$ & $0.59 \pm 0.12$ & $0.44 \pm 0.11$ & $0.54 \pm 0.10$ & $0.11 \pm 0.02$ & $0.13 \pm 0.01$ \\
\hline \multicolumn{6}{|c|}{ Alleles present in single copy $\left(44^{\circ} \mathrm{C}\right)$} \\
\hline tRNA ${ }^{\text {His }}$ & $0.64 \pm 0.09$ & $0.11 \pm 0.1$ & $0.43 \pm 0.08$ & $0.10 \pm 0.0$ & $0.11 \pm 0.01$ \\
\hline tRNA ${ }^{\text {Pro }}$ & $0.74 \pm 0.11$ & $0.15 \pm 0.02$ & $0.54 \pm 0.14$ & $0.15 \pm 0.03$ & $0.15 \pm 0.06$ \\
\hline tRNA ${ }^{\text {Asn }}$ & $0.96 \pm 0.02$ & $0.64 \pm 0.02$ & $0.96 \pm 0.03$ & $0.53 \pm 0.03$ & $0.53 \pm 0.06$ \\
\hline tRNA ${ }^{\text {Cys }}$ & $0.64 \pm 0.08$ & $0.29 \pm 0.03$ & $0.59 \pm 0.04$ & $0.19 \pm 0.03$ & $0.23 \pm 0.02$ \\
\hline \multicolumn{6}{|c|}{ Alleles present in six-to-eight copies $\left(30^{\circ} \mathrm{C}\right)$} \\
\hline tRNA ${ }^{H \text { is }}$ & $0.65 \pm 0.05$ & $0.61 \pm 0.12$ & $0.48 \pm 0.03$ & $0.10 \pm 0.01$ & $0.11 \pm 0.02$ \\
\hline tRNA Pro & $0.73 \pm 0.03$ & $0.74 \pm 0.02$ & $0.64 \pm 0.09$ & $0.15 \pm 0.03$ & $0.21 \pm 0.05$ \\
\hline tRNA ${ }^{\text {Asn }}$ & $0.97 \pm 0.02$ & $0.96 \pm 0.02$ & $0.97 \pm 0.03$ & $0.40 \pm 0.03$ & $0.46 \pm 0.04$ \\
\hline tRNA ${ }^{\text {Cys }}$ & $0.81 \pm 0.11$ & $0.74 \pm 0.09$ & $0.66 \pm 0.04$ & $0.19 \pm 0.02$ & $0.16 \pm 0.01$ \\
\hline \multicolumn{6}{|c|}{ Alleles present in six-to-eight copies $\left(44^{\circ} \mathrm{C}\right)$} \\
\hline tRNA ${ }^{\mathrm{His}}$ & $0.74 \pm 0.06$ & $0.28 \pm 0.03$ & $0.43 \pm 0.03$ & $0.16 \pm 0.01$ & $0.18 \pm 0.02$ \\
\hline tRNA ${ }^{\text {Pro }}$ & $0.70 \pm 0.05$ & $0.23 \pm 0.06$ & $0.60 \pm 0.03$ & $0.21 \pm 0.02$ & $0.29 \pm 0.03$ \\
\hline tRNA ${ }^{\text {Asn }}$ & $0.98 \pm 0.03$ & $0.90 \pm 0.03$ & $0.97 \pm 0.04$ & $0.64 \pm 0.07$ & $0.58 \pm 0.06$ \\
\hline tRNA $^{\text {Cys }}$ & $0.71 \pm 0.09$ & $0.56 \pm 0.12$ & $0.59 \pm 0.11$ & $0.20 \pm 0.03$ & $0.20 \pm 0.04$ \\
\hline
\end{tabular}

Represents the average and the standard deviations from the mean of either three or four independent determinations for each condition listed. Processed fraction is as described in Figure 5.

the actual cause for the loss of cell viability in an RNase E deletion mutant.

\section{MATERIALS AND METHODS}

\section{Bacterial strains}

The E. coli K-12 strains used in this study were all derived from MG1693 (rph-1 thyA715) (Arraiano et al. 1988) and are listed in Table 5. Strains SK3475, SK3500, SK3538, SK3540, SK3541, SK3543, SK3559, SK3563, SK3564, SK5065, and SK5067 were constructed either by standard plasmid transformation protocols or plasmid displacement as previously described (Ow et al. 2000; Ow and Kushner 2002).

\section{Growth and viability studies}

Overnight standing cultures of various strains in Luria broth supplemented with thymine $(50 \mu \mathrm{g} / \mathrm{mL})$ and kanamycin $(25 \mu \mathrm{g} / \mathrm{mL})$, chloramphenicol $(20 \mu \mathrm{g} / \mathrm{mL})$, or spectinomycin $(20 \mu \mathrm{g} / \mathrm{mL})$, where appropriate, were diluted 1:1000 into prewarmed fresh medium and shaken at $30^{\circ} \mathrm{C}$ or $37^{\circ} \mathrm{C}$. Cultures were monitored with a KlettSummerson Colorimeter (no. 42 green filter). For the $44^{\circ} \mathrm{C}$ growth curves, cultures were initially grown with shaking at $37^{\circ} \mathrm{C}$ until they reached 40 Klett units (no. 42 green filter) above background and then were shifted to $44^{\circ} \mathrm{C}$.

\section{Microscopic observation of cells and nucleoids}

The $30^{\circ} \mathrm{C}$ samples were taken from exponentially growing cultures $\left(1 \times 10^{8}\right.$ cells $\left./ \mathrm{mL}\right)$. The cultures were then shifted to $44^{\circ} \mathrm{C}$. Cell densities were kept between 1 and $2 \times 10^{8}$ cells/ $\mathrm{mL}$ by diluting the cultures with fresh prewarmed medium. The $44^{\circ} \mathrm{C}$ samples were taken $2 \mathrm{~h}$ after the temperature shift. The cells were immobilized and stained with DAPI (4',6-diamino-2-phenyl-indole) as previously described (Hiraga et al. 1989). After immersion oil was put on the cover slip, the cells were photographed at $100 \times$ magnification with a Hamamatsu digital camera (C-4742-95) mounted on a Zeiss fluorescence microscope equipped with Nomarski optics and Improvision Openlab software.

\section{Oligonucleotide primers}

The sequences of the various oligonucleotides used in these experiments are available upon request.

\section{Plasmid constructions}

The plasmids described below were generated using overlapping polymerase chain reaction (PCR) techniques and the high fidelity $P f u$ DNA polymerase (Stratagene). For the construction of pDHK11 (Fig. 1A), a 2.2-kb fusion DNA fragment was synthesized that contained the regulatory region, ribosome binding site, and ATG start codon of rne along with the $r n g^{+}$sequence that included 15 base-pair (bp) encoding an additional five amino acids (RKGIN) upstream of the native RNase G translation start codon (Briant et al. 2003). The ATG from rne replaced the GTG from rng such that a total of six extra amino acids were synthesized at the amino terminus of the RNase G protein derived from pDHK11. First, an rne gene fragment $(640 \mathrm{bp})$ was amplified by PCR using the primers RNE-UP and RNE-OE1 and pQLK26 plasmid DNA (Ow et al. 2000) as a template. In addition, an rng gene fragment (1579 bp) was amplified by PCR using the primers RNG-OE1 and RNGantisense and pUGK24 plasmid DNA (Ow et al. 2003) as template. The RNE-UP and RNG-antisense primers were engineered to contain EcoRI and XbaI sites, respectively. Subsequently, overlap extension PCR with primers RNE-OE1 and RNG-OE1 was used to generate a $2.2-\mathrm{kb}$ fusion DNA fragment containing the rne gene fragment $(640 \mathrm{bp})$ and $r n g$ gene fragments (1579 bp). The amplified fusion DNA fragment was cloned into pWSK129 (Wang and Kushner 1991), which had been digested with EcoRI and XbaI, to generate $\mathrm{pDHK} 11$.

Plasmid pDHK23 (encoding the native form of RNase G) (Fig. 1A) is identical to pDHK11 except for the GTG (putative upstream start codon derived from $r n g$ ) was changed to CTG to prevent translation initiation from this location, and a canonical ribosome binding site (AGGAGG) was inserted $7 \mathrm{nt}$ upstream of the ATG start codon to produce the native form of RNase G (Fig. 1A). To make these changes, a 658-bp rne DNA fragment was amplified by PCR using the primers RNE-UP and RNE-upstream and pQLK26 plasmid DNA as template along with a rng gene fragment (1561 bp) that was amplified by using the primers RNG-RBS and RNG-antisense and pUGK24 plasmid DNA as template. The 
TABLE 5. Bacterial strains and plasmids DNA used in this study

\begin{tabular}{|c|c|c|}
\hline & Genotype & Source of reference \\
\hline \multicolumn{3}{|l|}{ Strain } \\
\hline MG1693 & rph-1 thyA715 & E. coli Genetic Stock Center \\
\hline SK2538 & rng::cat $\mathrm{Cm}^{\mathrm{r}}$ & Ow et al. (2003) \\
\hline SK2585 & rne-1 recA56 $6^{a}$ pUGK $24\left(\right.$ rng $\left.^{+}, \mathrm{Km}^{r}\right)$ & Ow et al. (2003) \\
\hline SK2594 & rne-1 recA56 $/$ pUGK $31\left(\mathrm{rng}^{+}, \mathrm{Km}^{r}\right)$ & Ow et al. (2003) \\
\hline SK2685 & 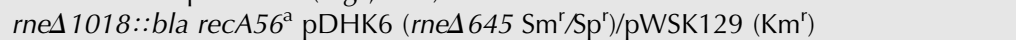 & Ow and Kushner (2002) \\
\hline SK3475 & rne-1 recA56 $/ \mathrm{pDHK}^{\mathrm{b}} 1^{\mathrm{b}}\left(\mathrm{rng}^{+} \mathrm{Km}^{\mathrm{r}}\right)$ & This study \\
\hline SK3500 & rne-1 recA56 $/ \mathrm{pDHK} 23\left(\right.$ rng $\left.^{+} \mathrm{Km}^{\mathrm{r}}\right)$ & This study \\
\hline SK3538 & rne-1 recA56 $/$ pDHK26 (rng-248/ Kmr) & This study \\
\hline SK3540 & rne-1 recA56а/pDHK28 (rng-219/ $\left.\mathrm{Km}^{\mathrm{r}}\right)$ & This study \\
\hline SK3541 & rned 1018::bla recA56 /pDHK26 $\left(r n g-248 \mathrm{Km}^{\mathrm{r}}\right)$ & This study \\
\hline SK3543 & rned 1018::bla recA56a/pDHK28 (rng-219 Kmr) & This study \\
\hline SK3559 & rne-1 recA56a/pDHK34 (rng-219, $\left.\mathrm{Km}^{\mathrm{r}}\right)$ & This study \\
\hline SK3563 & rned 1018::bla recA56 /pDHK29 $\left(r n g-248 \mathrm{Sm}^{\mathrm{r}} / \mathrm{Sp}^{\mathrm{r}}\right) / \mathrm{pWSK} 129\left(\mathrm{Km}^{\mathrm{r}}\right)$ & This study \\
\hline SK3564 & rned 1018::bla recA56 $/$ pDHK30 $\left(r n g-219 \mathrm{Sm}^{\mathrm{r}} / \mathrm{Sp}^{\mathrm{r}}\right) / \mathrm{pWSK} 129\left(\mathrm{Km}^{\mathrm{r}}\right)$ & This study \\
\hline SK5065 & rne-1 recA56 $6^{a}$ pRNG3 (placZrng $\left.{ }^{+} \mathrm{Ap}^{r}\right)^{\mathrm{C}}$ & This study \\
\hline SK5067 & rne-1 recA56a /pRNG1200 $\left(\mathrm{rng}^{+} \mathrm{Km}^{\mathrm{r}}\right)^{\mathrm{d}}$ & This study \\
\hline SK6610 & rne-1 recA56 $6^{\mathrm{a}}$ & Claverie-Martin et al. (1989) \\
\hline SK9714 & 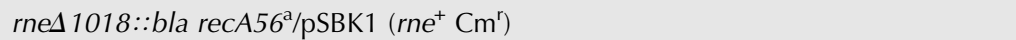 & Ow et al. (2000) \\
\hline SK9937 & rned 1018::bla recA56а/pMOK13 $\left(\right.$ rne-1 $\left.\mathrm{Cm}^{\mathrm{r}}\right)$ & Ow et al. (2000) \\
\hline SK9957 & rned $1018::$ bla recA56 a pMOK15 $\left(\right.$ rne $\left.\Delta 610 \mathrm{Cm}^{r}\right)$ & Ow et al. (2000) \\
\hline SK9987 & rne $\Delta 1018::$ bla recA56 $/$ pMOK21 $\left(r n e \Delta 645 \mathrm{Sm}^{\mathrm{r}} / \mathrm{Sp}^{r}\right)$ & Ow and Kushner (2002) \\
\hline SK10143 & 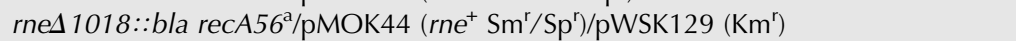 & Ow and Kushner (2002) \\
\hline SK10144 & rned 1018:: bla recA56\% $/$ pMOK45 $\left(\right.$ rne-1 $\left.\mathrm{Sm}^{\mathrm{r}} / \mathrm{Sp}^{\mathrm{R}}\right) / \mathrm{pWSK} 129\left(\mathrm{Km}^{\mathrm{r}}\right)$ & Ow and Kushner (2002) \\
\hline \multicolumn{3}{|c|}{ 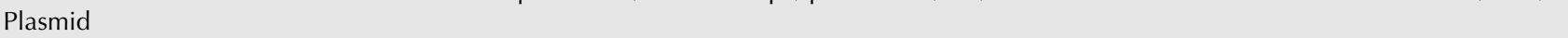 } \\
\hline pDHK6 & Single-copy plasmid with $r n e \Delta 645 \mathrm{Sm}^{r} / \mathrm{Sp}^{\mathrm{r}}$ & Ow and Kushner (2002) \\
\hline $\mathrm{pDHK} 11^{\mathrm{b}}$ & $\begin{array}{l}\text { Six-to-eight copy plasmid with } r^{+} g^{+} \text {(along with six additional amino } \\
\text { acids [MRKGIN] at the } 5^{\prime} \text { end and the regulatory region and ribosome } \\
\text { binding site of } r n g \text { have been replaced with those derived from } r n e) \mathrm{Km}^{r} \\
\text { (Fig. 1) }\end{array}$ & This study \\
\hline pDHK23 & $\begin{array}{l}\text { Six-to-eight copy plasmid with } r n g^{+} \text {( } r n g \text {-native form with the regulatory } \\
\text { region and ribosome binding site of } r n g \text { has been replaced with those } \\
\text { from rne and a canonical ribosome binding site) } \mathrm{Km}^{\mathrm{r}} \text { (Fig. 1) }\end{array}$ & This study \\
\hline pDHK26 & Six-to-eight-copy plasmid with $r n g-248 \mathrm{Km}^{\mathrm{r}}$ & This study \\
\hline pDHK28 & Six-to-eight-copy plasmid with $r n g-219 \mathrm{Km}^{\mathrm{r}}$ & This study \\
\hline pDHK29 & Single-copy plasmid with $r n g-248 \mathrm{Sm}^{r} / \mathrm{Sp}^{r}$ & This study \\
\hline pDHK30 & Single-copy plasmid with $r n g-219 \mathrm{Sm}^{\mathrm{r}} / \mathrm{Sp}^{\mathrm{r}}$ & This study \\
\hline pDHK32 & $\begin{array}{l}\text { Six-to-eight-copy plasmid with } r n g-219 \mathrm{Km}^{\mathrm{r}} \text { (derived by PCR site-directed } \\
\text { mutagenesis) }\end{array}$ & This study \\
\hline pDHK33 & $\begin{array}{l}\text { Six-to-eight-copy plasmid with } r n g-248 \mathrm{Km}^{\mathrm{r}} \text { (derived by PCR site-directed } \\
\text { mutagenesis) }\end{array}$ & This study \\
\hline pDHK34 & Six-to-eight-copy plasmid with $r n g-219 \mathrm{Km}^{\mathrm{r}}$ (contains $r n g$ regulatory sequences) & This study \\
\hline pDHK35 & Six-to-eight-copy plasmid with $r n g-248 \mathrm{Km}^{\mathrm{r}}$ (contains $r n g$ regulatory sequences) & This study \\
\hline pDHK38 & $\begin{array}{l}\text { Six-to-eight-copy plasmid with rne-rng Chimera } 1 \text { (amino acids 213-281 of RNase } \\
\text { G were replaced with those from RNase E) } \mathrm{Km}^{r}\end{array}$ & This study \\
\hline pDHK39 & $\begin{array}{l}\text { Six-to-eight-copy plasmid with rne-rng Chimera } 2 \text { (amino acids from 1-280 } \\
\text { of RNase G were replaced with those from RNase E) } \mathrm{Km}^{r}\end{array}$ & This study \\
\hline pDHK40 & $\begin{array}{l}\text { Six-to-eight-copy plasmid with rne-rng Chimera } 3 \text { (amino acids } 280-489 \text { of } \\
\text { RNase G were replaced with amino acids } 280-418 \text { from RNase E) } \mathrm{Km}^{r}\end{array}$ & This study \\
\hline pMOK13 & Six-to-eight-copy plasmid with rne- $1 \mathrm{Cm}^{\mathrm{r}}$ & Ow et al. (2000) \\
\hline pMOK15 & Six-to-eight-copy plasmid with $r n e \Delta 610 \mathrm{Cm}^{\mathrm{r}}$ & Ow et al. (2000) \\
\hline $\mathrm{pMOK} 21$ & Six-to-eight-copy plasmid with $r n e \Delta 645 \mathrm{Sm}^{\mathrm{r}} / \mathrm{Sp}^{\mathrm{r}}$ & Ow and Kushner (2002) \\
\hline pMOK40 & Single-copy plasmid with $\mathrm{Sm}^{\mathrm{r}} / \mathrm{Sp}^{\mathrm{r}}$ & Ow and Kushner (2002) \\
\hline pMOK44 & Single-copy plasmid with $r n e^{+} \mathrm{Sm}^{r} / \mathrm{Sp}^{r}$ & Ow and Kushner (2002) \\
\hline pMOK45 & Single-copy plasmid with $r n e-1 \mathrm{Sm}^{r} / \mathrm{Sp}^{\mathrm{r}}$ & Ow and Kushner (2002) \\
\hline pRNG3 ${ }^{c}$ & $\begin{array}{l}\text { Six-to-eight-copy plasmid with extended form of } r n g^{+} \text {and six histidines at the } \\
\text { carboxy terminus under the control of the lacZ promoter } A p^{r}\end{array}$ & Lee et al. (2002) \\
\hline pRNG1200 & $\begin{array}{l}\text { High-copy-number pUC plasmid with extended form of } r^{+} g^{+} \text {with a modified } \\
\text { rng promoter } \mathrm{Km}^{\mathrm{r}}\end{array}$ & Deana and Belasco (2004) \\
\hline
\end{tabular}


TABLE 5. Continued

\begin{tabular}{|c|c|c|}
\hline & Genotype & Source of reference \\
\hline pSBK1 & Six-to-eight-copy plasmid with $r n e^{+} \mathrm{Cm}^{r}$ & Ow et al. (2000) \\
\hline pUGK24 & Six-to-eight-copy plasmid with $r n g^{+} \mathrm{Km}^{r}$ & Ow et al. (2003) \\
\hline pUGK31 & 30-50-copy plasmid with $\mathrm{rng}^{+} \mathrm{Km}^{\mathrm{r}}$ & Ow et al. (2003) \\
\hline pWSK129 & Six-to-eight-copy plasmid with $\mathrm{Km}^{\mathrm{r}}$ & Wang and Kushner (1991) \\
\hline
\end{tabular}

${ }^{a}$ All strains containing the recA56 allele also carry the $s r I D 300:: \operatorname{Tn} 10 \mathrm{Tc}^{r}$ insertion mutation. All strains contain the thy A715 and $r p h-1$ alleles. ${ }_{\mathrm{p}} \mathrm{pHK} 11$ encodes an RNase $\mathrm{G}$ protein with six additional amino acids at its amino terminus.

'Plasmid pRNG3 carries $\mathrm{rng}^{+}$(along with six additional amino acids [MRKGIN] at the 5' end and six histidines at the 3' end) under the control of the lacZ promoter (Lee et al. 2002).

dPlasmid pRNG1200 carries $\mathrm{rng}^{+}$(along with six additional amino acids [MRKGIN] at the $5^{\prime}$ end) and a modified rng promoter (Deana et al. 1996).

RNE-upstream and RNG-RBS primer sequences were used for overlapping extension PCR to generate a 2.2-kb fusion DNA fragment that was subsequently cloned into pWKS129 as described for pDHK11.

To generate pDHK31, a 2.2-kb EcoRI/NotI DNA fragment containing the complete rne-rng fusion from pDHK23 was cloned into the single-copy vector pMOK40 (Ow and Kushner 2002) that had been digested with EcoRI and NotI.

pDHK29 (rng-248 Sm $\left.{ }^{\mathrm{r}} / \mathrm{Sp}^{\mathrm{r}}\right)$ and pDHK30 $\left(r n g-219 \mathrm{Sm}^{\mathrm{r}} / \mathrm{Sp}^{\mathrm{r}}\right)$ were made by cloning the 2.2-kb EcoRI/NotI DNA fragments from pDHK26 and pDHK28, respectively, into the EcoRI/NotI sites of pMOK40 (Ow and Kushner 2002). Plasmids pDHK29, pDHK30, and pDHK31 all contained the single-copy mini-F origin of DNA replication.

Plasmid pDHK38 (containing two RNase G fragments, one from the $\mathrm{N}$ terminus to amino acid 213 [including the $\mathrm{S} 1$ and $5^{\prime}$ sensor regions] and one including the C-terminal $r n g$ coding sequence for amino acids 281-488 (DNase I domain and Zn-link) along with the rne coding sequences for amino acids 213-281 (RNase H domain) was constructed by employing a two-step overlap extension PCR procedure. The regulatory region for this chimeric construct was derived from RNase $\mathrm{E}$ as described for pDHK23. To generate the $\mathrm{N}$-terminal 1.5-kb DNA fragment containing rne/rng sequences (1.3 $\mathrm{kb}$ ) and the $206 \mathrm{bp}$ from rne, a 1.3-kb rne/rng DNA fragment was amplified using primers RNE-UP and RNG-1260 down and plasmid pDHK23 as a template. In addition, a 206-bp rne DNA fragment was amplified using primers RNE-1280up and RNE-1486down and plasmid pQLK26 (Ow et al. 2000) as a template. Overlap extension PCR was then used to generate an N-terminal fragment of $1.5 \mathrm{~kb}$. The C-terminal 715-bp rng fragment was amplified using the prime RNG1486up and RNG-antisense along with pUGK24 as the template. The second overlap extension PCR was performed to generate a 2.2-kb fusion DNA fragment containing the $1.5-\mathrm{kb}$ rne/rng/rne DNA fragment and the downstream 715-bp rng fragment. The amplified chimeric rne/rng gene was cloned into pWSK129 (Wang and Kushner 1991) as described for pDHK11.

Plasmid pDHK39 (containing the regulatory region and first 281 amino acids of RNase E [S1, 5' sensor and RNase H subdomains] fused to the rng coding sequence for amino acids 282-488) was constructed by first amplifying a $1.5-\mathrm{kb}$ rne DNA fragment using primers RNE-UP and RNE-1486down and pQLK26 plasmid DNA as a template. In addition a 715-bp rng DNA fragment was amplified using primer RNG-1486up and RNG-antisense and pUGK24 plasmid DNA as a template. The RNE-1486down and RNA-1486up primers were used for the overlap PCR. The fusion fragment was cloned into pWSK129 as described for pDHK11

Plasmid pDHK40 (containing the regulatory region of RNase E, the first 280 amino acids of RNase G [S1, 5' sensor and RNase $\mathrm{H}$ subdomains] along with amino acids 281-418 from RNase E [DNase I subdomain and Zn-link]) was constructed by first amplifying a $1.5-\mathrm{kb}$ rne/rng DNA fragment using primers RNE-UP and RNG+278down and pDHK23 plasmid DNA as a template. In addition, a 450-bp rne DNA fragment was amplified using primers RNE+279up and RNE+417down and pMOK21 (rned645) plasmid DNA (Ow et al. 2003) as a template. The RNE+417down primer contained a XbaI site. The fusion fragment, generated using the RNG+278down and RNE+279up primer sequences, was subsequently cloned into pWSK129 as described for pDHK11.

All the plasmid constructions were verified using a combination of DNA sequencing and Western blot analysis. Western blot analysis of RNase E/G Chimeric proteins 1 and 3 employed a polyclonal antiRNase $\mathrm{G}$ antibody that was kindly provided by G. Mackie (Briant et al. 2003). RNase E/G Chimeric protein 2 was detected using a MAP antibody raised against the first 20 amino acids of RNase E (Ow et al. 2000). To determine if the RNase $G$ proteins were biologically active, steady-state RNA was isolated from independent transformants in an rng::cat genetic background (SK2538), and the presence or absence of the 16.3S rRNA precursor was determined as described by Wachi et al. (1999).

\section{Site-directed mutagenesis}

Overlapping PCR was used to individually introduce the two different single nucleotide changes in pDHK23. The $\mathrm{G} \rightarrow \mathrm{T}$ transversion at the first base pair of the codon encoding amino acid 219 and the $\mathrm{G} \rightarrow \mathrm{A}$ transition at the first base pair of amino acid 248 resulted in plasmids pDHK32 and pDHK33, respectively. Plasmids pDHK34 (rng-219 $\left.\mathrm{Km}^{\mathrm{r}}\right)$ and pDHK35 $\left(r n g-248 \mathrm{Km}^{\mathrm{r}}\right)$ were constructed to determine the effect of the two independent single amino acid substitutions on RNase $G$ when the proteins were synthesized from the native $r n g$ regulatory region instead of from rne promoters. In this case, the experiment was identical to that described above for pDHK32 and pDHK33, except that pUGK24 $\left(r n g^{+} \mathrm{Km}^{\mathrm{r}}\right)(\mathrm{Ow}$ et al. 2003) plasmid DNA was used as a template. Specific experimental details are available upon request. The presence of the predicted point mutations in the four plasmids was confirmed by manual plasmid DNA sequencing using fmol DNA Cycle Sequencing System Kit (Promega) as instructed by the manufacturer. 


\section{Western analysis}

Western blot analysis of RNase E, RNase G, and RNase G derivatives and the RNase E/G chimeric proteins was performed as described by Ow et al. (2000) and Ow and Kushner (2002). Protein concentrations were determined by the Bio-Rad protein assay with bovine serum albumin as the standard. Protein samples (2-100 $\mu \mathrm{g}$ for RNase G) were electrophoresed in an 8\% SDSpolyacrylamide gels and electrotransferred to PVDF membranes (ImmobilonTM-P; Millipore) using a Bio-Rad Mini-Protean 3 electrophoretic apparatus. The membranes were then probed with either RNase E (1:2000 dilution) or RNase G (1:10,000 dilution) antibodies using the ECL Plus Western Blotting Detection Kit (GE Healthcare) as specified by the manufacturer. The RNase G antibody was kindly provided by G. Mackie (Briant et al. 2003) and was preincubated with a $1 \mathrm{mg}$ of protein extract from RNase G-deficient E. coli cells (SK2538 rng::cat) (Ow et al. 2003) prior to use. The RNase E MAP antibody was raised against the first 20 amino acids of RNase E (Ow et al. 2000). Protein bands were quantified using a Storm 840 PhosphorImager (GE Healthcare) equipped with ImageQuant v.5.2 software (Molecular Dynamics).

\section{Northern analysis}

Total RNA extraction and mRNA Northern blot analysis were done according to the procedures described by O'Hara et al. (1995) and Burnett (1997). The steady-state RNAs used for the 5S rRNA and tRNA Northern blots were obtained from exponential cultures grown either at $30^{\circ} \mathrm{C}$ or after shift to $44^{\circ} \mathrm{C}$ for $120 \mathrm{~min}$. Northern analysis of tRNAs and 5S rRNA ( $5 \mu \mathrm{g} /$ lane) were done as described by Ow et al. (2000) and Ow and Kushner (2002). Probes for the 5S rRNA ("PB5S") (Babitzke et al. 1993) and tRNAs (hisR, cysT, proM, asn) were oligonucleotides (Ow and Kushner 2002) complementary to the mature species and were $5^{\prime}$-end-labeled with ${ }^{32} \mathrm{P}$ using T4 polynucleotide kinase. For quantification, the RNA samples were run on a $1.25 \%$ agarose gel and probed for $16 \mathrm{~S}$ rRNA using the ${ }^{32} \mathrm{P}-5^{\prime}$-end-labeled primer 16 S1586 (Ow et al. 2000). mRNA half-lives were calculated using least-squares linear regression analysis.

\section{Computer modeling of RNase G structure}

The protein sequence of RNase $G$ was compared against the PDB database by PSI-BLAST (Altschul et al. 1997). Three PDB entries, $2 \mathrm{bx} 2,2 \mathrm{c} 4 \mathrm{r}$, and $2 \mathrm{c} 0 \mathrm{~b}$, were selected as homologous templates for the next step of molecular modeling. All three sequences were derived from the catalytic domain of $E$. coli RNase E. The sequence identity between RNase $\mathrm{G}$ and the catalytic domain of RNase E was $34.1 \%$. To generate the model shown in Supplemental Figure S1, the inter/intra restraints ratio was set to 0.9 . The margins in the distance restraints and angle restraints were $0.5 \AA$ and $1.0 \AA$, respectively. The maximum number of distance restraints was 20,000. Three models were generated using Geno3D (http://geno3d-pbil. ibcp.fr), an online homology modeling tool (Combet et al. 2002). The model with the lowest energy is presented in Supplemental Figure S1. In this model, $0.9 \%$ of the residues occupied disallowed regions of the Ramachandran plot. The root-mean-square deviation between this model and the RNase E templates range 1.48-1.66 A. The model of RNase $\mathrm{G}$ and the $3 \mathrm{D}$ structure of RNase $\mathrm{E}$ were analyzed and viewed with PyMol (http://pymol.sourceforge.net/).

\section{ACKNOWLEDGMENTS}

We thank J. Shivas for excellent technical assistance and B. Mohanty and T. Perwez for critical reading of the manuscript. pRNG3 and pRNG120 were graciously provided by Dr. S. Cohen and Dr. J.G. Belasco, respectively. This work was supported in part by a grant (GM57220) from the National Institute of General Medical Sciences to S.R.K.

Received January 25, 2010; accepted April 12, 2010.

\section{REFERENCES}

Altschul SF, Madden TL, Schaffer AA, Zhang J, Zhang Z, Miller W, Lipman DJ. 1997. Gapped BLAST and PSI-BLAST: A new generation of protein database search programs. Nucleic Acids Res 25: 3389-3402.

Apirion D, Lasser AB. 1978. A conditional lethal mutant of Escherichia coli which affects the processing of ribosomal RNA. J Biol Chem 253: $1738-1742$.

Arraiano CM, Yancey SD, Kushner SR. 1988. Stabilization of discrete mRNA breakdown products in ams pnp $r n b$ multiple mutants of Escherichia coli K-12. J Bacteriol 170: 4625-4633.

Babitzke P, Kushner SR. 1991. The Ams (altered mRNA stability) protein and ribonuclease $\mathrm{E}$ are encoded by the same structural gene of Escherichia coli. Proc Natl Acad Sci 88: 1-5.

Babitzke P, Granger L, Olszewski J, Kushner SR. 1993. Analysis of mRNA decay and rRNA processing in Escherichia coli multiple mutants carrying a deletion in RNase III. J Bacteriol 175: 229-239.

Betat H, Rammelt C, Martin G, Morl M. 2004. Exchange of regions between bacterial poly(A) polymerase and the CCA-adding enzyme generates altered specificities. Mol Cell 15: 389-398.

Briant DJ, Hankins JS, Cook MA, Mackie GA. 2003. The quartenary structure of RNase G from Escherichia coli. Mol Microbiol 50: 1381-1390.

Briegel KJ, Baker A, Jain C. 2006. Identification and analysis of Escherichia coli ribonuclease E dominant-negative mutants. Genetics 172: 7-15.

Burnett WV. 1997. Northern blotting of RNA denatured in glyoxal without buffer recirculation. Biotechniques 22: 668-671.

Callaghan AJ, Marcaida MJ, Stead JA, McDowall KJ, Scott WG, Luisi BF. 2005. Structure of Escherichia coli RNase E catalytic domain and implications for RNA turnover. Nature 437: 1187-1191.

Celesnik H, Deana A, Belasco JG. 2007. Initiation of RNA decay in Escherichia coli by 5' pyrophosphate removal. Mol Cell 27: 79-90.

Claverie-Martin F, Diaz-Torres MR, Yancey SD, Kushner SR. 1989. Cloning of the altered mRNA stability (ams) gene of Escherichia coli K-12. J Bacteriol 171: 5479-5486.

Combet C, Jambon M, Deleage G, Geourjan C. 2002. Geno3D: Automatic comparative molecular modelling of protein. Bioinformatics 18: 213-214.

Deana A, Belasco JG. 2004. The function of RNase G in Escherichia coli is constrained by its amino and carboxyl termini. Mol Microbiol 51: 1205-1217.

Deana A, Ehrlich R, Reiss C. 1996. Synonymous codon selection controls in vivo turnover and amount of mRNA in Escherichia coli bla and ompA genes. J Bacteriol 178: 2718-2720.

Goldenberg D, Azar I, Oppenheim AB. 1996. Differential mRNA stability of the $\operatorname{csp} A$ gene in the cold-shock response of Escherichia coli. Mol Microbiol 19: 241-248.

Hajnsdorf E, Regnier P. 1999. E. coli rpsO mRNA decay: RNase E processing at the beginning of the coding sequence stimulates poly(A)-dependent degradation of the mRNA. J Mol Biol 286: 1033-1043.

Hajnsdorf E, Steier O, Coscoy L, Teysset L, Régnier P. 1994. Roles of RNase E, RNase II and PNPase in the degradation of the rpsO transcripts of Escherichia coli: Stabilizing function of RNase II and 
evidence for efficient degradation in an ams pnp $r n b$ mutant. EMBO J 13: 3368-3377.

Hajnsdorf E, Braun F, Haugel-Nielsen J, Le Derout J, Régnier P. 1996. Multiple degradation pathways of the $r p s O$ mRNA of Escherichia coli. RNase E interacts with the $5^{\prime}$ and $3^{\prime}$ extremities of the primary transcript. Biochimie 78: 416-424.

Hankins JS, Zappavigna C, Prud'homme-Genereux A, Mackie GA. 2007. Role of RNA structure and susceptibility to RNase $\mathrm{E}$ in regulation of a cold shock mRNA, cspA mRNA. J Bacteriol 189: 4353-4358.

Hiraga S, Niki H, Ogura T, Ichinose C, Mori H, Ezaki B, Jaffe A. 1989. Chromosome partitioning in Escherichia coli: Novel mutants producing anucleate cells. J Bacteriol 171: 1496-1505.

Kaga N, Umitsuki G, Nagai K, Wachi M. 2002. RNase G-dependent degradation of the eno mRNA encoding a glycolysis enzyme enolase in Escherichia coli. Biosci Biotechnol Biochem 66: 2216-2220.

Kuwano M, Ono M, Endo H, Hori K, Nakamura K, Hirota Y, Ohnishi Y. 1977. Gene affecting longevity of messenger RNA: A mutant of Escherichia coli with altered mRNA stability. Mol Gen Genet 154: 279-285.

Lee K, Bernstein JA, Cohen SN. 2002. RNase G complementation of rne null mutation identified functional interrelationships with RNase E in Escherichia coli. Mol Microbiol 43: 1445-1456.

Li Z, Deutscher MP. 2002. RNase E plays an essential role in the maturation of Escherichia coli tRNA precursors. RNA 8: 97-109.

Li Z, Pandit S, Deutscher MP. 1999. RNase G (CafA protein) and RNase $E$ are both required for the $5^{\prime}$ maturation of $16 \mathrm{~S}$ ribosomal RNA. EMBO J 18: 2878-2885.

Lin-Chao S, Wei C-L, Lin Y-T. 1999. RNase E is required for the maturation of $s s r A$ and normal ssrA RNA peptide-tagging activity. Proc Natl Acad Sci 96: 12406-12411.

Lopez PJ, Marchand I, Joyce SA, Dreyfus M. 1999. The C-terminal half of RNase E, which organizes the Escherichia coli degradosome, participates in mRNA degradation but not rRNA processing in vivo. Mol Microbiol 33: 188-199.

Lundberg U, Altman S. 1995. Processing of the precursor to the catalytic RNA subunit of RNase P from Escherichia coli. RNA 1: 327-334.

Mackie GA. 1991. Specific endonucleolytic cleavage of the mRNA for ribosomal protein S20 of Escherichia coli requires the products of the ams gene in vivo and in vitro. J Bacteriol 173: 2488-2497.

Mackie GA. 1998. Ribonuclease $\mathrm{E}$ is a $5^{\prime}$-end-dependent endonuclease. Nature 395: 720-723.

Masse R, Escorcia FE, Gottesman S. 2003. Coupled degradation of a small regulatory RNA and its mRNA targets in Escherichia coli. Genes Dev 17: 2374-2383.

Mohanty BK, Kushner SR. 2008. Rho-independent transcription terminators inhibit RNase P processing of the secG leuU and metT tRNA polycistronic transcripts in Escherichia coli. Nucleic Acids Res 36: 364-375.

O'Hara EB, Chekanova JA, Ingle CA, Kushner ZR, Peters E, Kushner SR. 1995. Polyadenylylation helps regulate mRNA decay in Escherichia coli. Proc Natl Acad Sci 92: 1807-1811.
Okada Y, Wachi M, Hirata A, Suzuki K, Nagai K, Matsuhashi M. 1994. Cytoplasmic axial filaments in Escherichia coli cells: Possible function in the mechanism of chromosome segregation and cell division. J Bacteriol 176: 917-922.

Otsuka Y, Yonesaki T. 2005. A novel endoribonuclease, RNase LS, in Escherichia coli. Genetics 169: 13-20.

Ow MC, Kushner SR. 2002. Initiation of tRNA maturation by RNase E is essential for cell viability in E. coli. Genes Dev 16: 1102-1115.

Ow MC, Liu Q, Kushner SR. 2000. Analysis of mRNA decay and rRNA processing in Escherichia coli in the absence of RNase E-based degradosome assembly. Mol Microbiol 38: 854-866.

Ow MC, Liu Q, Mohanty BK, Andrew ME, Maples VF, Kushner SR. 2002. RNase E levels in Escherichia coli are controlled by a complex regulatory system that involves transcription of the rne gene from three promoters. Mol Microbiol 43: 159-171.

Ow MC, Perwez T, Kushner SR. 2003. RNase G of Escherichia coli exhibits only limited functional overlap with its essential homologue, RNase E. Mol Microbiol 49: 607-622.

Perwez T, Kushner SR. 2006. RNase Z in Escherichia coli plays a significant role in mRNA decay. Mol Microbiol 60: 723-737.

Perwez T, Hami D, Maples VF, Min Z, Wang BC, Kushner SR. 2008. Intragenic suppressors of temperature-sensitive rne mutations lead to the dissociation of RNase E activity on mRNA and tRNA substrates in Escherichia coli. Nucleic Acids Res 36: 5306-5318.

Ray BK, Apirion D. 1981. Transfer RNA precursors are accumulated in Escherichia coli in the absence of RNase E. Eur J Biochem 114: 517-524.

Tamura M, Lee K, Miller CA, Moore CJ, Shirako Y, Kobayashi M, Cohen SN. 2006. RNase E maintenance of proper FtsZ/FtsA ratio required for nonfilamentous growth of Escherichia coli cells but not for colony-forming ability. J Bacteriol 188: 5145-5152.

Tock MR, Walsh AP, Carroll G, McDowall KJ. 2000. The CafA protein required for the $5^{\prime}$-maturation of $16 \mathrm{~S}$ rRNA is a $5^{\prime}$-end-dependent ribonuclease that has context-dependent broad sequence specificity. J Biol Chem 275: 8726-8732.

Umitsuki G, Wachi M, Takada A, Hikichi T, Nagia K. 2001. Involvement of RNase $\mathrm{G}$ in in vivo mRNA metabolism in Escherichia coli. Genes Cells 6: 403-410.

Wachi M, Umitsuki G, Nagai K. 1997. Functional relationship between Escherichia coli RNase E and the CafA protein. Mol Gen Genet 253: 515-519.

Wachi M, Umitsuki G, Shimizu M, Takada A, Nagai K. 1999. Escherichia coli cafA gene encodes a novel RNase, designated as RNase G, involved in processing of the $5^{\prime}$ end of $16 \mathrm{~S}$ rRNA. Biochem Biophys Res Commun 259: 483-488.

Wachi M, Naoko K, Umitsuki G, Clarke DP, Nagai K. 2001. A novel RNase $\mathrm{G}$ mutant that is defective in degradation of adhE mRNA but proficient in the processing of $16 \mathrm{~S}$ rRNA precursor. Biochem Biophys Res Commun 289: 1301-1306.

Wang RF, Kushner SR. 1991. Construction of versatile low-copynumber vectors for cloning, sequencing and expression in Escherichia coli. Gene 100: 195-199. 

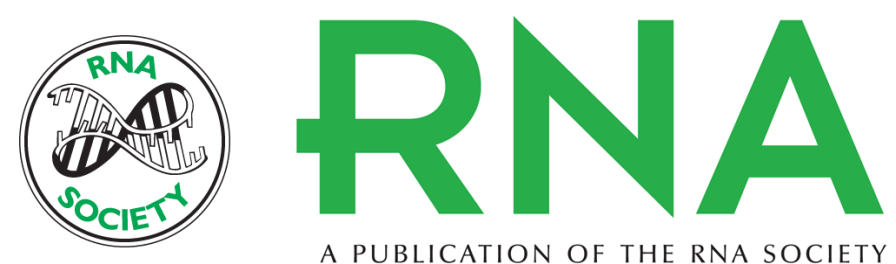

A PUBLICATION OF THE RNA SOCIETY

\section{Single amino acid changes in the predicted RNase $\mathrm{H}$ domain of Escherichia coli RNase G lead to complementation of RNase E deletion mutants}

Dae-hwan Chung, Zhao Min, Bi-Cheng Wang, et al.

RNA 2010 16: 1371-1385 originally published online May 27, 2010

Access the most recent version at doi:10.1261/rna.2104810

References This article cites 50 articles, 19 of which can be accessed free at:

http://rnajournal.cshlp.org/content/16/7/1371.full.html\#ref-list-1

License

Email Alerting Receive free email alerts when new articles cite this article - sign up in the box at the Service top right corner of the article or click here. 